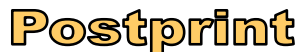

Version définitive du manuscrit publié dans / Final version of the manuscript published in : Infection, Genetics and Evolution, 2011,11, 812-824. The original publication is available at http://www.sciencedirect.com/science/article/pii/S1567134811000621. DOI: 10.1016/j.meegid.2011.02.020.

\section{The hallmarks of "green" viruses: do plant viruses evolve differently from the others?}

\author{
Desbiez C, Moury B, Lecoq H
}

INRA, Unité de Pathologie Végétale UR407, F-84140 Montfavet, France

Corresponding author : cecile.desbiez@avignon.inra.fr

\section{Introduction}

2. Taxonomy of plant viruses and relation to viruses infecting other hosts

3. Mechanisms of evolution in plant viruses and their relative importance 3.1 Mechanisms of evolution

\subsubsection{Mutation}

3.1.2 Recombination

3.1.2.1 Intergenera/kingdom: acquisition of plant genes

3.1.2.2 Intra- and interspecific recombination

3.1.2.3 Viral integration into host genome

3.2 Long-term evolution, speciation and molecular clock

4. Specific adaptation to plant hosts

4.1 Adaptation to plants: intra-plant movement

4.2 Vector transmission

4.2.1 Factors involved in transmission

4.2.2 Modification of vector fitness and behaviour

4.3 Evolutionary pressures during transmission

4.4 Overcoming of resistance mechanisms

4.4.1 Major resistance genes

4.4.2 Gene silencing

5. Conclusion: evolution of plant viruses relative to their hosts

\begin{abstract}
All viruses are obligatory parasites that must develop tight interactions with their hosts to complete their infectious cycle. Viruses infecting plants share many structural and functional similarities with those infecting other organisms, particularly animals and fungi. Quantitative data regarding their evolutionary mechanisms - generation of variability by mutation and recombination, changes in populations by selection and genetic drift- have been obtained only recently, and appear rather similar to those measured for animal viruses.

This review presents an update of our knowledge of the phylogenetic and evolutionary characteristics of plants viruses and their relation to their plant hosts, in comparison with viruses infecting other organisms.
\end{abstract}

Keywords: Molecular mechanisms of evolution, adaptation, taxonomy 


\section{Introduction}

Whether viruses are really living entities or parasitic (symbiotic) organelles is still an open question, and the recent discovery of giant viruses containing concomitantly DNA and RNA and encoding key components of the protein translation apparatus (Raoult et al., 2004) has made things apparently more confusing (Moreira and Lopez-Garcia, 2009; Raoult and Forterre, 2008 and Correspondences thereafter). It is sometimes considered that viruses are the arbiters of life and that only organisms that can be infected by a virus are living indeed. However, since viruses themselves can sometimes be infected by smaller viruses (La Scola et al., 2008) or by satellites, the definition is still open. Attempts to classify viruses like other forms of life using biological and morphological criteria and name them with latin binomials were unsuccessful. Besides, although the first described and later crystallized virus was the plant virus tobacco mosaic virus (TMV), connexions between plant and animal virologists have been for a time so limited that the same acronyms were attributed to totally different viruses, CMV for example meaning unambiguously cytomegalovirus for animal virologists, and cucumber mosaic virus for plant virologists. The development of molecular biology and characterization of the genome structure and function of many plant and animal viruses has revealed many common features suggesting identical origins and evolution mechanisms to a certain point, and allowing a common classification. However, plant and animal viruses have adapted to differential constraints related to the host-pathogen interactions and dissemination mechanisms that have shaped some features of the virus genomes. In this review, we will present an update of our knowledge of the characteristics of plants viruses and their relation to their plant hosts, in comparison with viruses infecting other organisms.

\section{Taxonomy of plant viruses and relation with viruses infecting other hosts}

\subsection{Plant virus taxonomy}

Since the first observations of plant viruses, their classification was made very challenging by their obligate parasitism and high phenotypic variability and plasticity. The first tools developed, mostly biological and serological, proved insufficient to distinguish unambiguously virus species and establish relationships between viral isolates. The development of molecular techniques during the last 30 years gave access to the genomic organization of viruses and sequence similarities between viral genomes. Since their first molecular characterizations, viruses have appeared as particularly variable in genome nature (DNA or RNA, single or double-stranded), organization and expression mechanisms (Miller et al., 2007; Zaccomer et al., 1995). Polythetic criteria based on virion morphology, molecular organization of the genome, percentage of sequence identity with known viruses, biology... are now used to classify viruses into a single scheme that aims to "reflect their evolutionary relationships, i.e. their individual phylogenies", after the recommendations of the International Committee for Taxonomy of Viruses (ICTV) (Table 1). In the 2005 ICTV report (Fauquet et al., 2005) that described about 6000 virus species -all hosts included-, 3142 species were simply "unassigned”, but thanks to the rapidly increasing number of sequences available, virus taxonomy is rapidly evolving, and more and more "unassigned" viruses are getting included in newly defined genera, families and orders. In 2005, three orders, only one of them, the Mononegavirale (containing Monopartite Negative-stranded RNA viruses that appear to be monophyletic) including plant viruses, were accepted. In 2009, the ICTV acknowledged 6 orders, 3 of which containing plant viruses (http://ictvonline.org/virusTaxonomy.asp?version=2009) (Table 1). Despite the striking biological differences between plant and animal viruses, molecular criteria have established that many of them share similarities in genome organization considered as consistent with virus phylogeny; they were originally assigned into "supergroups" or "superfamilies" that do not have a recognized taxonomic status. For single-stranded RNA viruses, two such supergroups, "picorna-like" and "alpha-like", have been described for more than 15 years (Goldbach and de Haan, 1994). With our view of viral diversity and phylogeny getting more complete, more and more plant and animal viruses within these supergroups are now clustered into 
common orders and families (Table 1). Eighteen families containing plant viruses were accepted by the ICTV in 2009 (Table 1); plant viruses are classified into circa 90 genera -the number is continuously increasing-, containing from one to almost 200 species (http://ictvonline.org/virusTaxonomy.asp?version=2009) (Table 1). Ten percent of the genera (vs. $20 \%$ in 2005) have not been assigned to any family so far.

Contrary to all cellular organisms and a majority of animal viruses, most plant viruses known so far have a single-stranded RNA genome (Table 1). Strikingly, non reverse transcribing, doublestranded DNA viruses that represent about $50 \%$ of the viruses infecting other kingdoms have never been observed in plants. The lack of large dsDNA viruses in plants is usually explained by the constraints related to the presence of cell walls in plant cells and the need for plant viruses to migrate through plasmodesmata (see 4.1). Also, genome segmentation is much more common in plant than in animal viruses (Fauquet et al., 2005a; Holmes 2009). However, the virion diameter and genome size of the vertebrate-infecting dsDNA polyomaviridae (40-45 nm diameter; $5 \mathrm{kpb})$ or papillomaviridae $(55 \mathrm{~nm}, 6.8-8.4 \mathrm{~kb})$ do not exceed that of the plant-infecting fijiviruses (dsRNA, 65-70 nm, 29kbp in 10 segments) or tospoviruses (ssRNA(-), 80-110 nm, $17 \mathrm{kbp}$ in 3 segments) (Fauquet et al., 2005a). Genome size in RNA and ssDNA plant viruses is probably constrained not only by encapsidation and migration limits, but also by the high mutation rate (see 3.1) that threatens the maintenance of genetic information integrity in large genomes.

Many plant viruses are transmitted by insects, and sometimes multiply in both plant and insect hosts, so it has been suggested that insect viruses were at the origin of some plant viruses (Morse, 1994). This concerns particularly the families Rhabdoviridae and Bunyaviridae (ssRNA-) that include plant, insect and vertebrate-infecting members (Table 1). The dsRNA viruses Reoviridae also multiply efficiently both in plants and insects.

Nevertheless some plant viruses, particularly cryptic viruses belonging to the family Partitiviridae (latent dsRNA viruses that seem to be very common in plants) are more related to fungal viruses (Roossinck, 2003; Roossinck, 2010). This concerns also the large dsRNA endornaviruses that have long been overlooked because they are usually asymptomatic but that appear to be quite common in plants and fungi (Fukuhara et al., 2006). They might derive from defective ssRNA viruses (Gibbs et al., 2000), and behave more like plasmids than true viruses, their genome being apparently neither translated nor encapsidated (Fukuhara et al., 2006). Pseudoviridae found in plants, fungi and invertebrate (Table 1), are more similar to retrotransposons than to infectious viruses.

The small ssDNA plant-infecting Geminiviridae and Nanoviridae share organizational and functional homology with the vertebrate-infecting Circoviridae (Gibbs and Weiller, 1999; Gronenborn, 2004; Vega-Rocha et al., 2007). Sequence data suggest that these viruses may descend from phytoplasmal replicons (Krupovic et al., 2009), and that the vertebrate-infecting circoviruses could have evolved from the plant-infecting nanoviruses (Gibbs and Weiller, 1999).

Viroids, the smallest infectious entities known so far, consisting of a small circular single-stranded RNA (250-400 bases) that does not encode any protein but can replicate autonomously when inoculated to a susceptible host, are known only in plants (Tsagris et al., 2008)

The number of existing virus species has long been grossly underestimated, as most studies focussed on viruses affecting human or animal health, or causing damages in agronomically important crops. The development of molecular techniques has increased our knowledge on virus genomic organization and evolution, and allowed for a dramatic increase in the number of species described. For plant viruses, in 1991 the $5^{\text {th }}$ ICTV report acknowledged less than 380 virus species, whereas in the $8^{\text {th }}$ report in 2004, more than 900 species were defined (cited from Rodoni, 2009). Almost $90 \%$ of plant viruses known so far were first isolated from cultivated plants, or occasionally agricultural weeds (Wren et al., 2006). Recent works on native weeds from Australia (Gibbs et al., 2008a), or from wild plants in Oklahoma and Costa Rica indicate a high prevalence of virus-like sequences (Muthukumar et al., 2009; Roossinck et al., 2010), usually unrelated to any symptom 
expression. Metagenomic approaches for viruses in different niches led to similar results for plant and non-plant viruses (e.g Bench et al., 2005; Culley et al., 2003; Edwards and Rohwer, 2005). Thus, the few thousands of known viruses may represent only a small percentage of total virus diversity.

\section{Mechanisms of evolution in plant viruses and their relative importance}

3.1 Mechanisms of evolution:

The mechanisms of plant virus evolution appear to be the same as for all organisms (Roossinck, 1997), but their strength and relative importance may be somewhat different. Quantitative estimations of their importance and evolutionary consequences have been obtained only recently and still remain limited.

\subsubsection{Mutation}

Mutation rates are considered as very high in RNA viruses as a consequence of the lack of proofreading activity of viral polymerases, and could be up to $10^{5}$ times higher than that of their hosts. Mutation rates have been estimated for an increasing number of animal and more recently plant viruses, and range from $10^{-6}$ to $10^{-4}$ mutations/nucleotide/replication cycle (Drake and Holland, 1999; Duffy et al., 2008; Elena et al., 2008; Malpica et al., 2002; Roossinck, 2003; Sanjuan et al., 2009; Sanjuan et al., 2010), and as high as $2.510^{-3}$ for viroids (Gago et al., 2009). They are frequently being corrected in order to reduce methodological biases (Sanjuan et al., 2010). Interestingly, estimated mutation rates for plant RNA viruses are in the lower side of the range usually observed for animal riboviruses (Tromas and Elena, 2010; Sanjuan et al., 2010). Although they use the polymerase of their host, ssDNA viruses appear to accumulate mutations at a frequency similar to that of RNA viruses (Duffy and Holmes, 2008; Duffy and Holmes, 2009). The mutation rate of viruses is close to the "error threshold", set at approximately the reciprocal of the genome size, beyond which the integrity of the genetic information is not maintained during replication (Holmes, 2003). The high mutation rate generates a tremendous potential variability that is usually considered as a way for RNA viruses to adapt to changing environments (Domingo and Holland, 1997). However, in the few plant virus systems studied most mutations are deleterious (Carrasco et al., 2007; Sanjuan, 2010) and the direct relation between adaptative value and high mutation rate is not obvious (Elena and Sanjuan, 2005; Garcia-Arenal and Fraile, 2003). The mutation rate of viruses, bacteria and eukaryotes seems to decrease linearly with the increase in genome size (Sanjuan et al., 2010), and it has been suggested that the emergence of replication fidelity mechanisms was central to the evolution of complexity in the early history of life (Gago et al., 2009).

\subsubsection{Recombination}

\subsubsection{Acquisition of plant genes}

Beyond the fact that viruses might have originated from modular assembly of eukaryotic or bacterial genes (see below), sequence data indicate that some plant viruses have acquired host genes relatively recently through horizontal transfer. As an example, all viruses in the family Closteroviridae contain a homologue of heat shock protein 70 (Hsp70h) gene (Dolja et al., 2006). This suggested that this acquisition took place early in the evolution of the family, as confirmed by phylogenetic analyses (Dolja et al., 2006). Hsp proteins are highly conserved cellular chaperones mostly associated with thermotolerance and cytoprotection in relation to apoptosis inhibition (Gober et al., 2005). The only other viruses encoding Hsp70h are Herpes simplex virus 2 (HSP2) (Gober et al., 2005), and the mimiviruses of the protozoan Acanthamoeba (Raoult et al., 2004). Closterovirus Hsp70h is required for efficient virion assembly and cell-to-cell virus movement, but contrary to plant or herpesvirus Hsp70, no ATPase-dependent chaperone activity was described and the protein probably has no apoptosis modulatory activity (Gober et al., 2005). 
Other cellular genes present in plant virus genomes include homologues of AlkB proteins, involved in the repair of DNA methylation damages in bacteria and eukaryotes. Sequence analyses indicated that AlkB homologues are present in at least 22 positive-stranded plant RNA viruses (Bratlie and Drablos, 2005) including most of the Flexiviridae, some Closteroviridae (Dolja et al., 2006) and one unique member of the family Potyviridae infecting Rubus spp. (Susaimuthu et al., 2008). Several viral AlkB proteins displayed RNA demethylation activity in vitro (van den Born et al., 2008). Sequence comparisons revealed that viral AlkB clustered together, and were more related to bacterial than to plant AlkB. Thus, the protein was probably acquired quite recently through interkingdom horizontal gene transfer into a Flexiviridae, maybe from plant pathogenic or symbiotic bacteria, and then disseminated horizontally via recombination between viruses (van den Born et al., 2008). Since most AlkB-encoding viruses infect woody or perennial hosts, it has been suggested that the RNA repair function of the protein could help to maintain genome integrity during long-term infection of these hosts.

More recently, two other Potyviridae were shown to have acquired a cellular Maf/HAM1-like pyrophosphatase (Mbanzibwa et al., 2009). HAM proteins act in bacterial or eukaryotic cells in reducing mutagenesis by intercepting noncanonical nucleoside triphosphates. No other virus is known to possess such proteins (Mbanzibwa et al., 2009).

Interestingly, what could be "recently acquired" host genes in plant viruses (since they are usually present only in a few members of a viral family) are putatively involved in reducing mutation and/or maintaining genome integrity and may constitute newly acquired viral weapons in the plantvirus arm race.

\subsubsection{Intra- or interspecific recombination}

Intra- or interspecific recombination has long been overlooked in plant viruses. Its occurrence in plant RNA viruses was demonstrated recently compared to animal viruses, in laboratory conditions imposing high selection pressure (Bujarski and Kaesberg, 1986), and it was long thought that it had only a very low frequency in natural conditions. However, phylogenetic analyses on a rapidly increasing number of viral sequences have revealed intra- and interspecific recombination in several genera of RNA viruses (Desbiez and Lecoq, 2004; Chare and Holmes, 2006; Valli et al., 2007). Pseudorecombination, i.e reassortment of genomic segments, was also observed between viruses with multipartite genomes, including cucumoviruses (Lin et al., 2004; Scott White et al., 1995), even if its frequency in natural conditions appears low (Fraile et al., 1997). Stable intergenera recombinants or reassortants yielded new virus species in some cases, e.g pea enation mosaic virus (PEMV, stable reassortant between a polerovirus and an umbravirus) (de Zoeten and Skaf, 2001) and poinsettia latent virus (PnLV, polemovirus, recombinant between a polerovirus and a sobemovirus) [aus dem Siepen, 2005 \#1165]. Recombinant isolates or viruses could display different biological properties and sometimes higher agronomic impact compared to parental strains (Desbiez and Lecoq, 2004; Paalme et al., 2004; Pierrugues et al., 2007), but the role of their recombinant nature on these characteristics has not been demonstrated. Intraspecific recombination was detected in many RNA viruses, with or without apparent recombination hotspots (Moury et al., 2006; Ohshima et al., 2007; Pagan and Holmes, 2010).

DNA viruses appear to be particularly recombination-prone. In experimental conditions where two quasi-isogenic cauliflower mosaic virus (CaMV, genus Caulimovirus) variants were inoculated to a plant, 60\% recombinant progeny was observed 21 days after inoculation, and a per base and per cycle recombination rate on the order of 2 to $4.10^{-5}$ was estimated (Froissart et al., 2005). Interspecific recombinants are particularly common among Geminiviridae, and such recombinants sometimes present a particularly high agronomical impact (Garcia-Andres et al., 2007a; Pita et al., 2001). In experimental conditions, recombinants could be detected after 4 months of co-infection by two viruses (Garcia-Andres et al., 2007b). Patterns of recombination "hotspots” or "coldspots" appear to be conserved among ssDNA viruses (Lefeuvre et al., 2009), probably in relation to constraints on protein structures and functions, and/or the replication mechanism of these viruses (Lefeuvre et al., 2007). 
Recombination is supposed to play an important role in allowing genetic exchanges, thus creating new genetic combinations with improved fitness (van der Walt et al., 2009) and/or limiting the effects of the accumulation of deleterious mutations -known as Muller's ratchet- in asexual populations with high mutation rate and important genetic drift (Moury et al., 2006; Roossinck, 1997).

3.1.2.3 Viral integration into host genome

Viral integration into host genome was observed for several plant ssDNA or dsDNA-reverse transcribing viruses (Bertsch et al., 2009; Harper et al., 2002). Begomovirus-related partial sequences were detected in the genome of four Nicotiana species, but not in nine others, and appear to result from two integration events during the speciation of Nicotiana (Ashby et al., 1997; Bejarano et al., 1996). The most common integration events concern the family Caulimoviridae, and Endogenous Pararetroviruses (EPRVs) have been described in the last decades in an increasing number of plant species (Bertsch et al., 2009; Harper et al., 2002; Staginnus and Richert-Pöggeler, 2006; Geering et al., 2010). Integrated sequences can be partial and non-infectious. For example, partial sequences of the caulimovirus rice tungro bacilliform virus (RTBV) are found in the genome of rice Oryza sativa and O. indica (Kunii et al., 2004). The sequences are incomplete and highly reassorted, and are not known to induce any infection of the plants. In contrast, several members of the Caulimoviridae that integrated into the genome of their host can be released and initiate infection when activated by plant stress, as observed notably for banana streak virus (BSV) in Musa after in vitro culture (Dallot et al., 2001; Staginnus and Richert-Pöggeler, 2006). Despite the risks associated with EPRV activation, viral sequences might have been maintained in the plant genome because they conferred a reduced susceptibility to infection with exogenous viruses (Bertsch et al., 2009; Kunii et al., 2004; Staginnus and Richert-Pöggeler, 2006).

Phylogenetic analyses allowed to date some integration events back to the speciation of their hosts: three integration events took place for RTBV during Oryza speciation (Kunii et al., 2004), whereas multiple events of BSV integration happened during the speciation of the genus Musa (Gayral and Iskra-Caruana, 2009).

\subsection{Long-term evolution, speciation and molecular clock}

Although no single protein seems to be monophyletic in all viruses, obvious sequence similarities in the most essential proteins suggest a common origin at least within some groups. The tremendous increase in viral sequences and analysis tools available allow analysing the phylogenic relationships between viruses and the relative importance of the different mechanisms of evolution. The most widely shared protein is the RNA-dependent RNA polymerase (RdRp) present in all ssRNA(+) viruses that was used successfully to establish phylogenic relationships between these viruses (Koonin, 1991; Koonin et al., 2009). Even if almost all viruses possess coat proteins (CP), these are not monophyletic, even between viruses that share obvious similarities in genome organization. For example, within the "picorna-like" supergroup of ssRNA viruses (Goldbach and de Haan, 1994; Koonin et al., 2009), the Potyviridae were excluded from the proposed Picornavirale order because their coat protein forming rod-shaped particles is completely different molecularly and functionally from the icosahedric CP of the order, and was probably acquired from an other origin (Le Gall et al., 2008). Using the RdRp and RNA helicase sequences -for viruses that had such a helicase- a phylogeny of the "picorna-like" supergroup was established. The strong correlation between host and viral phylogeny between the major supergroups of eukaryotes suggested that viral evolution began before the eukaryotic radiation (Koonin et al., 2009), thus dating virus appearance and evolution to over a billion years ago. The different clades within the picorna-like are supposed to have emerged by acquiring different proteins from eukaryotic, prokaryotic or bacteriophage origins (Koonin et al., 2009). Within families of plant viruses, speciation was frequently related to high genome plasticity: besides the "core" genome shared by all members of the family, a variable number of genes of eukaryotic or unknown source were acquired by recombination and/or gene duplication in the different species (Dolja et al., 2006; Valli et al., 2007; Martelli et al., 2007). 
Besides recombination, speciation was also achieved by progressive accumulation of mutations. Recent works using time series of viral sequences have allowed estimating a time scale associated with mutation fixation for an increasing number of plant viruses (for a review: see Gibbs et al., 2010). The fixation rate was in the range of $10^{-3}$ to $10^{-4}$ mutations/site/year (Fargette et al., 2008; Gibbs et al., 2008b; Pagan and Holmes, 2010). This contradicts earlier assumptions that since plant viruses were not submitted to the high selection pressure imposed to animal viruses by their host's immune system, they would evolve much more slowly. Thus, like animal viruses, plant viruses have "measurably evolving populations" (Drummond et al., 2003), and their evolutionary rates are similar to those observed for some animal viruses (Jenkins et al., 2002; Holmes 2009; Gibbs et al., 2010). For the potyviridae, luteoviridae and sobemoviruses, viral radiation was traced back to the mid-Holocene and the beginning of agriculture (Fargette et al., 2008; Gibbs et al., 2008b; Gibbs et al., 2010; Pagan and Holmes, 2010). Besides, several studies have shown that the extant populations of different viral species are only decades to centuries old, reflecting an evolutionary burst related to intensification of agricultural practices (Gibbs et al., 2010). Agriculture not only favours the spread of viruses by increasing the concentration of the same plant genotype in one spot and allowing long-distance dispersal of infected materials or contact between native infected plants and new susceptible crops (Jones, 2009; Gibbs et al., 2010), but also implies a strong human-driven selection different from the one of natural plant populations (Purugganan and Fuller, 2009). For human and animal viruses, it is also supposed to have changed the burden of virus infection, by creating much denser populations and enhancing contacts between humans and animals (Diamond, 2002); however, contrary to plant viruses, there is no evidence yet from molecular clock analysis of human viruses that their ancestry dates back from the beginning of agriculture (Holmes, 2009).

There is usually no strong correlation between viral phylogeny at the family or genus level and host plant phylogeny: the host range of a single plant virus frequently includes hosts belonging to different plant orders or even classes. This suggests an absence of co-evolution and easy switches in viral host range inside the Angiospermae (Gibbs et al., 2008b). Tobamoviruses that display congruent phylogenetic trees with their relative hosts were supposed to constitute an exception and have radiated with their plant lineages, i.e 100 million years ago (Gibbs, 1999), but recent analyses using coalescent methods suggest that their time of origin is rather within the last 100,000 years, more similar to other viral genera or families (Pagan et al., 2010).

The ultimate criterion for demarcation of virus species now frequently relies on a threshold percentage of identity in the whole sequence or on some particular protein(s) (Adams et al., 2005). However the high frequency of interspecific recombination in some families (Fauquet et al., 2008; Fauquet et al., 2005b) and the occasional presence of "clusters" of sequences close to the threshold values between strains and species (Adams et al., 2005) reveal the limits of this method. The taxonomic situation of viruses shares some similarity with that of bacteria, frequent gene transfers making it difficult to find definitive criteria for species delimitation (Peix et al., 2009; Riley and Lizotte-Waniewski, 2009).

\section{Specific adaptation to plant host}

Compared to animal viruses, plant viruses face two obvious constraints:

(1) the presence of cell walls in the hosts and the need to develop mechanisms allowing cell-to-cell movement and long-distance migration through the phloem, and

(2) the requirement in most cases of an intermediate (usually a biotic "vector") for plant-to-plant horizontal transmission -a situation similar to animal arboviruses but different from many other animal viruses-, due to the lack of movement of the host, the poor survival of viruses in the air or water and their inability to enter intact cells to initiate infection.

Although lacking the huge adaptability of the vertebrate immune system, plants also display efficient antiviral mechanisms and viruses have developed specific counter-defences.

\subsection{Adaptation to plants: intra-plant movement}


Plant cells are delimited by cell walls and interconnected through plasmodesmata that allow a very complex control of cell-to-cell exchanges (Maule, 2008). No plant virus has ever been observed to synthesise lytic enzymes that would allow its direct passage through the cell walls. Thus, contrary to animal viruses, plant viruses can not exit infected cells and move to adjacent ones by exocytosis or by cell lysis. Cell-to-cell movement requires a virus-induced increase in the size exclusion limit (SEL) of plasmodesmata. One or several viral proteins have been associated with movement in plant viruses (Deom et al., 1992; Koonin et al., 1991). Movement proteins of different viral families have low similarity, suggesting that such proteins have been acquired more than once during evolution, maybe from plant proteins involved in structure/function of plasmodesmata (Roossinck, 2003). Viral movement proteins (MP) have been shown to interact with plant proteins involved in molecular trafficking (Paape et al., 2006), and particularly with microtubules (Boyko et al., 2007). Different viral MPs seem to have evolved separately to exploit distinct intracellular trafficking pathways (Maule, 2008). Interestingly, an insect virus could replicate in barley protoplasts and infect systemically transgenic plants expressing the movement protein of TMV but not wild-type nontransgenics, showing that all functions required for the insect virus replication were supported by the plant cell, and that movement only was the key factor limiting plant infection (Dasgupta et al., 2001). The fact that some viruses are limited to phloem is usually regarded as a deficiency in movement. However, although mutations in the read-through protein of phloem-limited potato leafroll virus (PLRV, Polerovirus, family Luteoviridae) allowed the virus to infect all plant tissues, compensatory mutations were observed after a few months of infection and the virus reverted to a phloem limitation, indicating in this case a fitness cost associated with increased systemic movement (Peter et al., 2009).

Recent data indicate that strong genetic bottlenecks leading to an important genetic drift can take place during virus migration in plants (Elena et al., 2008). A small number of particles is involved in the infection of each cell. The multiplicity of infection (MOI) was estimated to 1.5-6 for TMV (Gonzalez-Jara et al., 2009), 5-6 for soil-borne wheat mosaic virus (Miyashita and Kishino, 2010) and 2 to 13 for CaMV (Gutierrez et al., 2010). Theses values are similar to or slightly higher than the MOI estimated for a few bacteriophages ( $\mathrm{MOI}=2$ to 3 ) and one insect-infecting virus (MOI= 4 to 5) (cited by Gonzalez-Jara et al., 2009). For TMV and CaMV, the MOI changed during the course of infection and decreased to 1 or 2 after a few days or weeks of infection. In experiments using viruses tagged with fluorescent markers, infected tissues formed "islands" exclusively infected by one or the other clone of the same virus. Co-infections were observed only in a limited number of cells in the contact zones between two islands (Dietrich and Maiss, 2003; Takahashi et al., 2007) whereas in the case of two completely different viruses, multiple infection of the cells was the rule (Dietrich and Maiss, 2003; Takahashi et al., 2007). The severe bottlenecks and/or low MOI related to virus migration can lead to stochastic variations (French and Stenger, 2005) and/or progressive differentiation along the branches or tiller of the host plant (French and Stenger, 2003; French and Stenger, 2005; Jridi et al., 2006). The MOI and/or bottlenecks seem to depend on the virus species. For wheat streak mosaic virus (WSMV, Tritimovirus) and TMV, the effective size of population during migration was estimated to 4 and 2-20 virus particles respectively, resulting in very severe bottlenecks (French and Stenger, 2003; Sacristan et al., 2003). For CaMV that presents a relatively high MOI (up to 13) with an effective size of population of several hundreds of genomes, the bottleneck was much more limited than in any other plant virus estimated so far (Monsion et al., 2008). Narrow bottlenecks ought to induce strong genetic drift putatively resulting in the accumulation of deleterious mutations through "Muller's ratchet" (see 3.1.2.2), but it has been suggested that bottlenecks during cell-to-cell movement of plant RNA viruses could help the selection pressure to work on trans-acting genes or elements by rapidly isolating the adaptative genomes from defective ones (Miyashita and Kishino, 2010). In the case of CaMV, the bottlenecks appear to be less severe, but the very high recombination rate of the virus (Froissart et al., 2005) might be another way to limit Muller's ratchet.

Bottlenecks and genetic drift during within-host migration seem to be common in plant viruses; they have also been observed at least occasionally in animal viruses, notably during the infection of 
mouse nervous system by poliovirus (Pfeiffer and Kirkegaard, 2006). It is not well known whether the bottlenecks in plants or animals are primarily explained by a "tough-transit model" where trafficking within the infected host is difficult for viruses, each particle having a very low probability of success, or a "burned-bridge model" where the first few viruses to enter very quickly trigger an antiviral state that limits the successful entry and spread of later viruses (Pfeiffer and Kirkegaard, 2006). 


\subsection{Vector transmission}

\subsubsection{Factors involved in transmission}

A large majority of plant viruses are transmitted by vectors, mostly insects. The molecular determinants for vector transmission have been well studied (Hogenhout et al., 2008; Ng and Falk, 2006; Sin et al., 2005). Besides the CP, “helper” proteins are involved in the vector transmissibility of several viral genera (Pirone and Blanc, 1996). Helper proteins from different viral families do not share structural similarity, suggesting independent evolutions. Helper proteins seem to act as "bridges" allowing binding between the $\mathrm{CP}$ and receptors located in the vector mouthparts (Blanc et al., 1997; Uzest et al., 2007). One advantage of the "helper" strategy for viruses could be a reduction of the selection pressure for transmissibility, since deficiencies in transmission can be easily trans-complemented by exogenous helper component (Froissart et al., 2002). Proteins or molecular motifs required for vector transmission are sometimes dispensable for virus infectivity. In tospoviruses that are among the rare enveloped plant viruses, the envelope is dispensable for plant infection but necessary for vector transmission that requires a complex virus cycle in the thrips vector (Nagata et al., 2000; Resende et al., 1991).

\subsubsection{Modification of vector fitness and behaviour}

Although the underlying mechanisms are not completely elucidated, viral infection in plants has been shown to modify the fitness and behaviour of insect vectors. This trait presents an interesting convergence with some arthropod-borne animal viruses that can manipulate the feeding behaviour of their vector (for a review see Lefèvre and Thomas, 2008). Viral infections have a wide range of effects on insect growth, survival and fecundity, ranging from detrimental to highly improving on these fitness parameters (Donaldson and Gratton, 2007; Hodge and Powell, 2008b). Indirect effects can also derive from plant viral infection. Thrips larvae grow faster on plants infected by tomato spotted wilt virus (TSWV, Tospovirus) (Belliure et al., 2008). Since large thrips larvae are less susceptible than small ones to predators, this favours the survival of a larger number of vectors and increases virus transmission (Belliure et al., 2008). In the PEMV/aphid/bean system, high parasitoid pressure decreased the longevity of aphids vectoring PEMV, but the aphids tended to disperse more efficiently to new hosts, increasing virus spread (Hodge and Powell, 2008a). Infection can also increase the attractiveness of plants, thus improving virus transmission. Aphids showed a preference for plants infected with Potyviridae or Luteoviridae (Eigenbrode et al., 2002; Fereres et al., 1999). Infected plants frequently turn yellow and this colour is attractive for aphids whether they are virus vectors or not (Hodge and Powell, 2008b) but besides, infected plants can emit volatiles that are attractive for insects (Eigenbrode et al., 2002; Fereres et al., 1999). Multiple infections by several viruses, a common situation in nature, can enhance the attractiveness of the plants and the fecundity of the aphids compared to single infections or healthy plants (Srinivasan and Alvarez, 2007).

It has been shown that infection of zucchini squash by CMV reduced greatly host-plant quality aphids performed poorly on infected plants and rapidly emigrated from them- but increased their attractiveness by inducing elevated emissions of plant volatiles. This represents a striking example of host manipulation by a virus resulting in increased transmission through modification of vector behaviour (Mauck et al., 2010). Some effects of CMV on aphids may be related to the ability of the viral $2 \mathrm{~b}$ protein to disrupt the jasmonic acid (JA) pathway involved in plant resistance to insects (Lewsey et al., 2010).

\subsection{Evolutionary pressures during transmission}

The ability to be transmitted exerts an obvious selection pressure on virus populations. Nontransmissible isolates are not expected to spread efficiently, although such isolates can sometimes develop epidemics at a moderate geographic scale, probably through assistance mechanisms with transmissible strains or viruses (Hu et al., 1996; Yakoubi, Desbiez and Lecoq, unpublished). When the selection pressure for vector transmissibility is lowered (repeated mechanical inoculations, vegetative propagation of the host, long-term maintenance in insect cells for viruses that multiply in 
plants and insects), the virus often loses its vector transmissibility (Legavre et al., 1996; Pu et al., 2011), indicating that the virus has to develop trade-offs between vector transmissibility and other fitness traits. This was confirmed by works on barley stripe mosaic virus that can be transmitted vertically or horizontally. When the virus was serially transmitted vertically or horizontally, its efficiency for vertical or horizontal transmission, respectively, increased, but it decreased for the alternative mode of transmission (Stewart et al., 2005). Constraints on genome evolution are frequently tested by estimating the ratio $\omega$ of non-synonymous (i.e amino-acid changing) to synonymous substitution rates in coding sequences. A value close to $\omega=1$ indicates neutrality, while $\omega<1$ and close to 0 suggests strong purifying (negative) selection, i.e high evolutionary constraints. Values $\omega>1$, indicating diversifying (positive) selection are rare in whole genes but can sometimes be observed in individual codons. A strong negative selection is usually observed in genome regions of plant or animal viruses involved in vector transmission (Chare and Holmes, 2004), but positive selection was detected at amino-acid positions involved in aphid transmission of CMV (Moury, 2004). Another important trait related to vector transmission is the fact that only a small fraction of the virus population present in an infected plant is acquired and transmitted by the vector. A strong bottleneck occurs at this step, potentially resulting in an important genetic drift (Ali et al., 2006; Nolasco et al., 2008). Recent data on non-persistently aphid transmitted viruses have revealed that as low as 1 to 2 infectious virus particles are transmitted on average by a single aphid ( Moury et al., 2007; Betancourt et al., 2008).

Vertical transmission of plant viruses can happen through seed transmission, although it is not very common, most viruses failing to invade the embryo (Johansen et al., 1994). Vegetative propagation, i.e asexual multiplication, is quite common in plants, and particularly in cultivated species, compared to most animals, and is very favourable for viruses: virus transmission to the offspring happens usually at $100 \%$ in this case, and the virus is already adapted to the progeny that has the same genetic characteristics as the parent (Rice, 1983). In the case of a geminivirus, the infection frequency of asexual host populations was much higher than in sexual populations, and the genetic diversity of the virus, particularly in a region involved in host adaptation, was higher in sexual populations (Ooi and Yahara, 1999).

We analysed the evolutionary constraints on the coat protein, involved in aphid transmission, of 30 potyviruses that are or are not transmitted vertically in natural conditions. At least $10 \mathrm{CP}$ sequences were aligned for each virus; putative recombinants were searched with GARD (Kosakovsky Pond et al., 2006) and eliminated if needed. The average $\omega$ value for each virus was estimated with the SLAC algorithm implemented in DATAMONKEY (Pond and Frost, 2005). The $\omega$ values ranged from 0.066 to 0.321 . There was no significant difference $(p=0.115)$ between the average $\omega$ of viruses transmitted horizontally only, or vertically by seed or by vegetative propagation of their hosts, indicating no evidence of differences in constraints on the CP (data not shown).

The important generation of mutants during the replication of viral genomes has led to the hypothesis that viral populations may function as quasispecies, i.e swarm of mutants centered on a "master" sequence, with the selection pressures applying to the whole population rather than on individual genomes (Eigen and Biebricher, 1988; Lauring and Andino, 2010; Manrubia et al., 2005). In the case of plant viruses, since very severe bottlenecks apply at different steps of the virus cycle, leading to an important genetic drift, it has been questioned whether the quasispecies concept could really apply (French and Stenger, 2005; Jenkins et al., 2001; Smith et al., 1997).

\subsection{Overcoming of plant virus resistance mechanisms}

4.4.1 Major resistance genes

Even though plants lack the huge plasticity of vertebrate adaptative immune system, they have developed very efficient virus control mechanisms, and viruses fight an evolutionary arm race with their hosts. Plant defences based on gene-for-gene interaction between plants and viruses are similar to what exists against fungal or bacterial pathogens, and present some similarity with innate 
immunity in vertebrates and insects (Nürnberger and Brunner, 2002). Any virus gene can be an avirulence gene targeted by dominant resistance genes of the host (so far, mostly presenting the same structure with Nucleotide binding site-Leucine rich repeats or NBS-LRR) (Kang et al., 2005; Jones and Dangl, 2006; Moffett, 2009). Interaction between avirulence and resistance gene triggers metabolic pathways leading to resistance (Kang et al., 2005; Jones and Dangl, 2006; Gomez et al., 2009). Recessive resistance genes against viruses are until now more frequent than against other pathogens. Recessive genes cloned so far belong to eukaryotic translation initiation complex (eIF4E or 4G) (for a review see Truniger and Aranda, 2009); resistance implies the loss of an interaction between viral protein(s) and the translation complex that hinders the multiplication of the virus (Léonard et al., 2000).

In spite of the high mutation rate and dispersion capacity of viruses (Garcia-Arenal and McDonald, 2003; McDonald and Linde, 2002), resistance genes against viruses are frequently more durable than against other pathogens (Garcia-Arenal and McDonald, 2003). Since virus genome is very compact and constrained, viruses, contrary to other plant pathogens, usually do not overcome resistances by large deletions or translocations, but mostly by point mutations. The overcoming of plant resistance genes by accumulation of point mutations, and the questions that it raises for virus control, appear similar to the overcoming of antiviral drugs in animal or human viruses (Richman, 2006), even if, unfortunately, plant and animal virologists have for long developed few comparative studies in this domain. Resistance breaking in plant viruses, or decreased susceptibility to antiviral drugs for animal viruses (Cuevas et al., 2005; Paredes et al., 2009), frequently imposes a fitness cost to viruses (Desbiez et al., 2003; Jenner et al., 2002; Janzac et al., 2010). Resistance durability is related to the number and nature of the mutations necessary for resistance breaking (Harrison, 2002; Fabre et al., 2009), but also to the constraints on virus avirulence factors (Janzac et al., 2009) and to the cost associated to the mutations for resistance breaking and/or the evolutionary intermediates leading to the resistance breaking variant (Fabre et al., 2009).

\subsubsection{Gene silencing}

Although gene silencing (or RNA inhibition, RNAi) is a very general phenomenon in eukaryotes and has recently earned the Nobel Prize to its discoverer in Caenorhabditis elegans-, it was first observed and seems to be particularly important in plants as a way to control viruses (Obbard et al., 2009). Double-stranded RNAs that represent the replicative forms of all RNA viruses are recognized by the "Dicer" complex of plants and cut ('diced') into short 21-24 nucleotide long fragments called short interfering RNAs (siRNA or viRNA). They are loaded into an effector complex (RISC for RNA-induced silencing complex), leading to the specific degradation of viral RNA (reviewed by Ding and Voinnet, 2007). In the plant-virus arms race, many viruses have evolved to express viral suppressors of silencing. At least 50 inhibitors of silencing have been identified from over 30 virus genera, both in plants and in animals (Li and Ding, 2006). Suppression of the viRNA pathway seems to be nearly universal in plant-RNA virus interactions (Ding and Voinnet, 2007; Marée et al., 2000). Some plant viruses even encode several inhibitors of silencing, notably citrus tristeza virus (CTV, closterovirus) encoding three inhibitors, among which the viral coat protein, that exhibit distinct features in silencing suppression (Obbard et al., 2009). Interestingly, silencing suppressors of different viral families have no structural similarity, even when they have similar functions (Obbard et al., 2009), suggesting that they have evolved independently and have only a functional homoplasy. An analysis of the evolutionary constraint ( $\omega$ ratio) of genes from 17 closely related pairs of ssRNA plant viruses revealed a significantly higher $\omega$ ratio for silencing inhibitors than for other genes, suggesting that diversifying selection applies on these genes as a response to plant defence mechanism (Obbard et al., 2009). 
Recent data on plant viruses indicate that they are submitted to multiple evolutionary pressures and develop trade-offs between different fitness components. Plant viruses can be "generalists" like CMV infecting more than 1000 species, or specialists like most potyviruses, each infecting a limited number of species. Even in generalists, some strain specificity is usually observed and adaptation to new hosts can have a fitness cost on alternative hosts (Elena et al., 2008; Wallis et al., 2007). Viruses must also obey trade-offs between mutational robustness (i.e the fact that most mutations are neutral regarding to fitness) and their ability to adapt to new environments, as demonstrated for two viroids in mutagenic vs. non-mutagenic environments (Codoner et al., 2006; Elena et al., 2008). The mode of transmission -horizontal vs. vertical- implies differences in virushost adaptation. An efficient vertical transmission requires that the plant has enough progeny with a good viability to insure virus maintenance. In vertical vs. horizontal transmission experiments involving brome streak mosaic virus (BSMV), vertically-transmitted viruses evolved towards lower aggressiveness compared to horizontally-transmitted ones (Elena et al., 2008; Stewart et al., 2005). Horizontally-transmitted viruses are also supposed to develop trade-offs between transmission efficiency and duration of infection, even if experimental data remain scarce (for a review see Froissart et al., 2010). Plants present different resistance mechanisms that can put selection pressures on different steps of the virus cycle (van den Bosch et al., 2006). Interestingly, positive selection and/or rapid evolution can be observed not only in viral genes involved in resistancebreaking, but also in some plant components interacting with viruses, suggestive of a long-term coevolutionary arms race (Charron et al., 2008). One common hypothesis regarding long-term plant virus interactions is that they should evolve towards lowered aggressiveness, since reducing plant longevity and growth is ultimately harmful for the virus. Symptom severity of plant viruses is frequently poorly correlated with viral load (Sacristan and Garcia-Arenal, 2008); symptoms appear as a deleterious side effect of virus infection, maybe in relation to virus-induced perturbations of the silencing pathway (plant miRNA metabolism) and/or other pathways in infected plants (Shiboleth et al., 2007). Plant tolerances, i.e high viral multiplication without symptoms, should be more durable than resistances (Roy and Kirchner, 2000; Salomon, 1999), but the few experimental data available do not always corroborate this assumptions (Desbiez et al., 2003). Data on natural infections of wild plants and putative plant-virus co-evolution in the absence of anthropic pressure are limited (for a review see Fraile and Garcia-Arenal, 2010), but the situations range from completely asymptomatic to severely diseased plants showing typical symptoms of mosaics, deformations, yellowing or stunting (Cooper and Jones, 2006; Poutaraud et al., 2004). In experimental virus infections on wild plants, variable levels of partial resistance or tolerance were observed, with a limited heritability (Carr et al., 2006); viral effects on plant fitness (measured as viable offspring) were more important in situation of competition, i.e when the density of plants was important (Pagan et al., 2009) and were modulated by the intrinsic characteristics and plasticity of plant genotypes (Carr et al., 2006; Pagan et al., 2009). In natural grasslands of California, the prevalence of generalist aphid-borne grass viruses was shown to be dependent of the host composition of the environment, which they could sometimes modify by reducing the fitness of infected plants (Power and Mitchell, 2004), but also, directly or through modification of host composition, of herbivore grazing (Borer et al., 2009) or abiotic factors such as phosphorus fertilization (Borer et al., 2010). Virus evolution is necessarily shaped by its obligate hosts, but the impact of viruses on their vectors as well as on their host plants can vary tremendously, from highly detrimental to neutral or even beneficial as improving vector growth or resistance to hyperparasitism, or plant resistance to abiotic stresses (Márquez et al., 2007; Xu et al., 2008). This highlights the multiple and complex range of interactions of plant viruses with their environment, the different selection pressures they must adapt to, and their diverse impacts on the ecosystems.

\section{References:}

Adams, M.J., Antoniw, J.F. and Fauquet, C. 2005. Molecular criteria for genus and species discrimination within the family Potyviridae. Arch. Virol. 150, 459-479. 
Ali, A., Li, H., Schneider, W.L., Sherman, D.J., Gray, S., Smith, D. and Roossinck, M. 2006. Analysis of genetic bottleneck during horizontal transmission of Cucumber mosaic virus. J. Virol. 80, 8345-8350.

Ashby, M.K., Warry, A., Bejarano, E.R., Khashoggi, A., Burrell, M. and Lichtenstein, C.P. 1997. Analysis of multiple copies of geminiviral DNA in the genome of four closely related Nicotiana species suggest a unique integration event. Plant Mol. Biol. 35, 313-321.

aus dem Siepen, M., Pohl, J.O., Koo, B.-J., Wege, C. and Jeske, H., 2005. poinsettia latent virus is not a cryptic virus, but a natural polerovirus-sobemovirus hybrid. Virology 336, 240-250.

Bejarano, E.R., Khashoggi, A., Witty, M. and Lichtenstein, C., 1996. Integration of multiple repeats of geminiviral DNA into the nuclear genome of tobacco during evolution. Proc. Natl. Acad.Sci. U.S.A 93, 759-764.

Belliure, B., Janssen, A. and Sabelis, M.W., 2008. Herbivore benefits from vectoring plant virus through reduction of period of vulnerability to predation. Oecologia 156, 797-806.

Bench, S.R., Hanson, T.E., Williamson, K.E., Ghosh, D., Radosovich, M., Wang, K. and Wommack, E., 2005. Metagenomic Characterization of Chesapeake Bay Virioplankton. Appl. Env. Microbiol. 73, 7629-7641.

Bertsch, C., Beuve, M., Dolja, V.V., Wirth, M., Pelsy, F., Herrbach, E. and Lemaire, O., 2009. Retention of the virus-derived sequences in the nuclear genome of grapevine as a potential pathway to virus resistance. Biol. Direct 4:21.

Betancourt, M., Fereres, A., Fraile, A. and Garcia-Arenal, F., 2008. Estimation of the effective number of founders that initiate an infection after aphid transmission of a multipartite plant virus. J. Virol. 82, 12416-12421.

Blanc, S., Lopez-Moya, J.-J., Wang, R., Garcia-Lampasona, S., Thornbury, D.W. and Pirone, T.P., 1997. A specific interaction between coat protein and helper component correlates with aphid transmission of a potyvirus. Virology 231, 141-147.

Borer, E.T., Mitchell, C.E., Power, A.G. and Seabloom, E.W., 2010. Consumers indirectly increase infection risk in grassland food webs. Proc. Natl. Acad.Sci. U.S.A 106, 503-506.

Borer, E.T., Seabloom, E.W., Mitchell, C.E. and Power, A.G., 2010. Local context drives infection of grasses by vector-borne generalist viruses. Ecology Letters 13, 808-810.

Boyko, V., Hu, Q., Seemanpillai, M., Ashby, J. and Heinlein, M., 2007. Validation of microtubuleassociated Tobacco mosaic virus RNA movement and involvement of microtubule-aligned particle trafficking. Plant J. 51, 589-603.

Bratlie, M.S. and Drablos, F., 2005. Bioinformatic mapping of AlkB homology domains in viruses. BMC Genomics 6, 1-15.

Bujarski, J.J. and Kaesberg, P., 1986. Genetic recombination between RNA components of a multipartite plant virus. Nature 321, 528-531.

Carr, D.E., Murphy, J.F. and Eubanks, M.D., 2006. Genetic variation and covariation for resistance and tolerance to Cucumber mosaic virus in Mimulus guttatus (Phrymaceae): a test for costs and constraints. Heredity 96, 29-38.

Carrasco, P., de la Iglesia, F. and Elena, S.F., 2007. Distribution of fitness and virulence effects caused by single-nucleotide substitutions in Tobacco etch virus. J. Virol. 81, 12979-12984.

Chare, E.R. and Holmes, E.C., 2004. Selection pressures in the capsid genes of plant RNA viruses reflect mode of transmission. J. Gen. Virol. 85, 3149-3157.

Chare, E.R. and Holmes, E.C., 2006. A phylogenetic survey of recombination frequency in plant RNA viruses. Arch. Virol. 151, 933-946.

Charron, C., Nicolaï, M., Gallois, J.-L., Robaglia, C., Moury, B., Palloix, A. and Caranta, C., 2008. Natural variation and functional analyses provide evidence for co-evolution between plant eIF4E and potyviral VPg. Plant J. 54, 56-68.

Codoner, F.M., Daros, J.-A., Sole, R.V. and Elena, S., 2006. The fittest versus the flattest: experimental confirmation of the quasispecies effect with subviral pathogens. PLoS Pathog. 2(12), e136. 
Cooper, I. and Jones, R.A.C., 2006. Wild plants and viruses: under-investigated ecosystems. Adv. Virus Res. 67, 1-47.

Cuevas, J.M., Sanjuan, R., Moya, A. and Elena, S.F., 2005. Mode of selection and experimental evolution of antiviral drugs resistance in vesicular stomatitis virus. Inf. Gen. Evol. 5, 55-65.

Culley, A.I., Lang, A.S. and Suttle, C.A., 2003. High diversity of unknown picorna-like viruses in the sea. Nature 424, 1054-1057.

Dallot, S., Acuña, P., Rivera, C., Ramírez, P., Côte, F., Lockhart, B.E. and Caruana, M.-L., 2001. Evidence that the proliferation stage of micropropagation procedure is determinant in the expression of banana streak virus integrated into the genome of the FHIA 21 hybrid (Musa AAAB). Arch. Virol. 146, 2179-2190.

Dasgupta, R., Garcia, B.H. and Goodman, R.M., 2001. Systemic spread of an RNA insect virus in plants expressing plant viral movement protein genes. Proc. Natl. Acad.Sci. U.S.A 98, 49104915.

de Zoeten, G.A. and Skaf, J.S., 2001. Pea enation mosaic and the vagaries of a plant virus. Adv. Virus Res. 57, 323-350.

Deom, C.M., Lapidot, M. and Beachy, R.N., 1992. Plant virus movement proteins. Cell 69, 221224.

Desbiez, C., Gal-On, A., Girard, M., Wipf-Scheibel, C. and Lecoq, H., 2003. Increase in Zucchini yellow mosaic virus symptom severity in tolerant zucchini cultivars is related to a point mutation in P3 protein and is associated with a loss of relative fitness on susceptible plants. Phytopathology 93, 1478-1484.

Desbiez, C. and Lecoq, H., 2004. The nucleotide sequence of Watermelon mosaic virus (WMV, Potyvirus) reveals interspecific recombination between two related potyviruses in the 5' part of the genome. Arch. Virol. 149, 1619-1632.

Diamond, J., 2002. Evolution, consequences and future of plant and animal domestication. Nature 418, 700-707.

Dietrich, C. and Maiss, E., 2003. Fluorescent labelling reveals spatial separation of potyvirus populations in mixed infected Nicotiana benthamiana plants. J. Gen. Virol. 84, 2871-2876.

Ding, S.-W. and Voinnet, O., 2007. Antiviral immunity directed by small RNAs. Cell 130, 413-426.

Dolja, V.V., Kreuze, J.F. and Valkonen, J.P.T., 2006. Comparative and functional genomics of closteroviruses. Virus Res. 117, 38-51.

Domingo, E. and Holland, J.J., 1997. RNA virus mutations and fitness for survival. Annu. Rev. Microbiol. 51, 151-178.

Donaldson, J.R. and Gratton, C., 2007. Antagonistic effects of soybean viruses on soybean aphid performance. Env. Entom. 36, 918-925.

Drake, J.W. and Holland, J.J. 1999. Mutation rates among RNA viruses. Proc. Natl. Acad.Sci. U.S.A 96, 13910-13913.

Drummond, A.J., Pybus, O.G., Rambaut, A., Forsberg, R. and Rodrigo, A.G., 2003. Measurably evolving populations. Trends Ecol. Evol. 18, 481-488.

Duffy, S. and Holmes, E.C., 2008. Phylogenetic evidence for rapid rates of molecular evolution in the single-stranded DNA begomovirus Tomato yellow leaf curl virus. J. Virol. 82, 957-965.

Duffy, S. and Holmes, E.C., 2009. Validation of high rates of nucleotide substitution in geminiviruses: phylogenetic evidence from East African cassava mosaic viruses. J. Gen. Virol. 90, 1539-1547.

Duffy, S., Shackelton, L.A. and Holmes, E.C.; 2008. Rates of evolutionary change in viruses: patterns and determinants. Nat. Rev. Genet. 9, 267-276.

Edwards, R.A. and Rohwer, F., 2005. Viral metagenomics. Nat. Rev. Microbiol. 3, 504-510.

Eigen, M. and Biebricher, C.K., 1988. Sequence space and quasispecies distribution. In: E. Domingo, J. Holand and P. Ahlquist (Eds), RNA Genetics, pp. 211-242. Vol. 3.3 vols. Boca Raton: CRC press. 
Eigenbrode, S.D., Ding, H.J., Shiel, P. and Berger, P.H., 2002. Volatiles from potato plants infected with potato leafroll virus attract and arrest the virus vector, Myzus persicae (Homoptera : Aphididae). Proc. R. Soc. Biol. Sci. 269, 455-460.

Elena, S. and Sanjuan, R., 2005. Adaptative value of high mutation rates of RNA viruses: separating causes from consequences. J. Virol. 79, 11555-11558.

Elena, S.F., Agudelo-Romero, P., Carrasco, P., Codoner, F.M., Martin, S., Torres-Barcelo, C. and Sanjuan, R., 2008. Experimental evolution of plant RNA viruses. Heredity 100, 478-483.

Fabre, F., Bruchou, C., Palloix, A. and Moury, B., 2009. Key determinants of resistance durability to plant viruses: Insights from a model linking within- and between-host dynamics. Virus Res. 141, 140-149.

Fargette, D., Pinel-Galzi, A., Sérémé, D., Lacombe, S., Hébrard, E., Traoré, O. and Konaté, G., 2008. Diversification of Rice yellow mottle virus and related viruses spans the history of agriculture from the Neolithic to the Present. PLoS Pathog. 4(8):e1000125.

Fauquet, C., Briddon, R.W., Brown, J.K., Moriones, E., Stanley, J., Zerbini, M. and Zhou, X., 2008. Geminivirus strain demarcation and nomenclature. Archi. Virol. 153, 783-821.

Fauquet, C., Mayo, M.A., Maniloff, J., Desselberger, U. and Ball, L.A., 2005a. Virus Taxonomy. Eigth report of the International Committee on Taxonomy of Viruses. Elsevier.

Fauquet, C., Sawyer, S., Idris, A.M. and Brown, J.K., 2005b. Sequence analysis and classification of apparent recombinant begomoviruses infecting tomato in the Nile and Mediterranean basins. Phytopathology 95, 549-555.

Fereres, A., Kampmeier, G.E. and Irwin, M.E., 1999. Aphid attraction and preference for soybean and pepper plants infected with Potyviridae. Ann. Entom. Soc. America 92, 542-548.

Fraile, A., Alonso-Prados, J.L., Aranda, M.A., Bernal, J.J., Malpica, J.M. and Garcia-Arenal, F., 1997. Genetic exchange by recombination or reassortment is infrequent in natural populations of a tripartite RNA plant virus. J. Virol. 71, 934-940.

Fraile, A. and Garcia-Arenal, F., 2010. The Coevolution of Plants and Viruses: Resistance and Pathogenicity. Adv. Virus Res.76, 1-32

French, R. and Stenger, D.C., 2003. Evolution of Wheat streak mosaic virus: dynamics of population growth within plants may explain limited variation. Annu. Rev. Phytopathol. 41, 199-214.

French, R. and Stenger, D.C., 2005. Population structure within lineages of Wheat streak mosaic virus derived from a common founding event exhibits stochastic variation inconsistent with the deterministic quasi-species model. Virology 343, 179-189.

Froissart, R., Michalakis, Y. and Blanc, S., 2002. Helper component-transcomplementation in the vector transmission of plant viruses. Phytopathology 92, 576-579.

Froissart, R., Roze, D., Uzest, M., Galibert, L., Blanc, S. and Michalakis, Y., 2005. Recombination every day: abundant recombination in a virus during a single multi-cellular host infection. PLoS Biol. 3(3):e89.

Froissart, R., Doumayrou, J., Vuillaume, F., Alizon, S. and Michalakis, Y. 2010. The virulencetransmission trade-off in vector-borne plant viruses: a review of (non-) existing studies. Phil. Trans. R. Soc. B 365, 1907-1918.

Fukuhara, T., Koga, R., Aoki, N., Yuki, C., Yamamoto, N., Oyama, N., Udagawa, T., Horiuchi, H., Miyazaki, S., Higashi, Y., Takeshita, M., Ikeda, K., Arakawa, M., Matsumoto, N. and Moriyama, H., 2006. The wide distribution of endornaviruses, large double-stranded RNA replicons with plasmid-like properties. Arch. Virol. 151, 995-1002.

Gago, S., Elena, S.F., Flores, R. and Sanjuan, R., 2009. Extremely high mutation rate of a hammerhead viroid. Science 323, 1308.

Garcia-Andres, S., Accotto, G.P., Navas-Castillo, J. and Moriones, E., 2007a. Founder effect, plant host, and recombination shape the emergent population of begomoviruses that cause the tomato yellow leaf curl disease in the Mediterranean basin. Virology 359, 302-312. 
Garcia-Andres, S., Tomas, D.M., Sanchez-Campos, S., Navas-Castillo, J. and Moriones, E., 2007b. Frequent occurrence of recombinants in mixed infections of tomato yellow leaf curl diseaseassociated begomoviruses. Virology 365, 210-219.

Garcia-Arenal, F. and Fraile, A., 2003. Variation and evolution of plant virus populations. Int. Microbiol. 6, 225-232.

Garcia-Arenal, F. and McDonald, B. 2003. An analysis of the durability of resistance to plant viruses. Phytopathology 93, 941-952.

Gayral, P. and Iskra-Caruana, M.L., 2009. Phylogeny of Banana Streak Virus reveals recent and repetitive endogenization in the genome of its banana host (Musa sp.). J. Mol. Evol. 69, 6580.

Geering, A. D. W., Scharaschkin, T. and Teycheney, P.-Y. 2010. The classification and nomenclature of endogenous viruese in the family Caulimoviridae. Arch. Virol. 155, 123-131.

Gibbs, A., 1999. Evolution and origins of tobamoviruses. Phil. Trans. R. Soc. B 354, 593-602.

Gibbs, A.J., Fargette, D., Garcia-Arenal, F. and Gibbs, M.J., 2010. Time - the emerging dimension of plant virus studies. J. Gen. Virol. 91, 13-22.

Gibbs, A.J., Mackenzie, A.M., Wei, K.-J. and Gibbs, M.J., 2008a. The potyviruses of Australia. Arch. Virol. 153, 1411-1420.

Gibbs, A.J., Ohshima, K., Phillips, M.J. and Gibbs, M.J. 2008b. The prehistory of potyviruses: their initial radiation was during the dawn of agriculture. PLoS One 3(6):e2523.

Gibbs, M.J., Koga, R., Moriyama, H., Pfeiffer, P. and Fukuhara, T., 2000. Phylogenetic analysis of some large double-stranded RNA replicons from plants suggests they evolved from a defective single-stranded RNA virus. J. Gen. Virol. 81, 227-233.

Gibbs, M.J. and Weiller, G.F., 1999. Evidence that a plant virus switched hosts to infect a vertebrate and then recombined with a vertebrate-infecting virus. Proc. Natl. Acad.Sci. U.S.A 96, 8022-8027.

Gober, M.D., Wales, S.Q. and Aurelian, L., 2005. Herpes simplex virus type 2 encodes a heat shock protein homologue with apoptosis regulatory functions. Frontiers Biosci. 10, 2788-2803.

Goldbach, R. and de Haan, P., 1994. RNA viral supergroups and the evolution of RNA viruses. In: S. Morse (Ed), The evolutionary biology of viruses, pp. 105-119. Raven Press, New York.

Gomez, P., Rodriguez-Hernandez, A.M., Moury, B. and Aranda, M.A., 2009. Genetic resistance for the sustainable control of plant virus diseases: breeding, mechanisms and durability. Eur. J. Plant Pathol. 125, 1-22.

Gonzalez-Jara, P., Fraile, A., Canto, T. and Garcia-Arenal, F., 2009. Multiplicity of infection of a plant virus varies during colonisation of its eukaryotic host. J. Virol. 83, 7487-7494.

Gronenborn, B., 2004. Nanoviruses: genome organisation and protein function. Vet. Microbiol. 98, 103-109.

Gutierrez, S., Yvon, M., Thébaud, G., Monsion, B., Michalakis, Y. and Blanc, S., 2010. Dynamics of the multiplicity of cellular infection in a plant virus. PLoS Pathog. 6(9). e1001113.

Harper, G., Hull, R., Lockhart, B. and Olszewski, N.E., 2002. Viral sequences integrated into plant genomes. Annu. Rev. Phytopathol. 40, 119-136.

Harrison, B.D., 2002. Virus variation in relation to resistance-breaking in plants. Euphytica 124, 181-192.

Hodge, S. and Powell, G., 2008a. Complex interactions between a plant pathogen and insect parasitoid via the shared vector-host: consequences for host plant infection. Oecologia 157, 387-397.

Hodge, S. and Powell, G., 2008b. Do plant viruses facilitate their aphid vectors by inducing symptoms that alter behavior and performance? Env. Entom. 37, 1573-1581.

Hogenhout, S.A., Ammar, E.-D., Whitfield, J.B. and Redinbaugh, M.G., 2008. Insect vector interactions with persistently transmitted viruses. Annu. Rev. Phytopathol. 46, 327-359.

Holmes, E.C., 2003. Error thresholds and the constraints to RNA virus evolution. Trends Microbiol. $11,543-546$. 
Holmes, E.C., 2009. The evolution and emergence of RNA viruses, 254 pp. Oxford Series in Ecology and Evolution, edited by P.H. Harvey and R.M. May. 1 vols. Oxford University Press.

Hu, W.Q., Pu, Z.Q., Xu, Z.G. and Fang, Z.D., 1996. A viral disease of broad bean caused by a nonaphid-transmissible strain of turnip mosaic virus. Plant Pathol. 45, 843-847.

Janzac, B., Fabre, F., Palloix, A. and Moury, B., 2009. Constraints on evolution of virus avirulence factors predict the durability of corresponding plant resistances. Mol. Plant Pathol. 10, 599610.

Janzac, B., Montarry, J., Palloix, A., Navaud, O. and Moury, B., 2010. A point mutation in the polymerase of Potato virus Y confers virulence towards the Pvr4 resistance of pepper and a high competitiveness cost in susceptible cultivar. Mol. Plant-Microbe Interact. 23, 823-830.

Jenkins, G.M., Rambaut, A., Pybus, O.G. and Holmes, E.C., 2002. Rates of molecular evolution in RNA viruses: a quantitative phylogenetic analysis. J. Mol. Evol. 54, 156-165.

Jenkins, G.M., Worobey, M., Woelk, C.H. and Holmes, E.C., 2001. Evidence for non-quasispecies evolution of RNA viruses. Mol. Biol. Evol. 18, 987-994.

Jenner, C.E., Wang, X., Ponz, F. and Walsh, J.A. 2002. A fitness cost for Turnip mosaic virus to overcome host resistance. Virus Res. 86, 1-6.

Johansen, E., Edwards, M.C. and Hampton, R.O., 1994. Seed transmission of viruses: current perspectives. Annu. Rev. Phytopathol. 32, 363-386.

Jones, J.D.G. and Dangl, J.L., 2006. The plant immune system. Nature 444, 323-329.

Jones, R.A.C. 2009. Plant virus emergence and evolution: Origins, new encounter scenarios, factors driving emergence, effects of changing world conditions, and prospects for control. Virus Res. 141, 113-130.

Jridi, C., Martin, J.-F., Marie-Jeanne, V., Labonne, G. and Blanc, S., 2006. Distinct viral populations differentiate and evolve independently in a single perennial host plant. J. Virol. 80, 2349-2357.

Kang, B.-C., Yeam, I. and Jahn, M., 2005. Genetics of plant virus resistance. Annu. Rev. Phytopathol. 43, 581-621.

Koonin, E.V.; 1991. The phylogeny of RNA-dependent RNA polymerases of positive-strand RNA viruses. J. Gen. Virol. 72, 2197-2206.

Koonin, E.V., Mushegian, A.R., Ryabov, E.V. and Dolja, V.V.; 1991. Diverse groups of plant RNA and DNA viruses share related movement proteins that may possess chaperone-like activity. J. Gen. Virol. 72, 2895-2903.

Koonin, E.V., Wolf, Y.I., Nagasaki, K. and Dolja, V.V., 2009. The Big Bang of picorna-like virus evolution antedates the radiation of eukaryotic supergroups. Nat. Rev. Microbiol. 6, 925-939.

Kosakovsky Pond, S.L., Posada, D., Gravenor, M.B., Woelk, C.H. and Frost, S.D.W., 2006. Automated phylogenetic detection of recombination using a genetic algorithm. Mol. Biol. Evol. 23, 1891-1901.

Krupovic, M., Ravantti, J.J. and Bamford, D.H., 2009. Geminiviruses: a tale of a plasmid becoming a virus. BMC Evol. Biol. 9, 112.

Kunii, M., Kanda, M., Nagano, H., Uyeda, I., Kishima, Y. and Sano, Y., 2004. Reconstruction of putative DNA virus from endogenous rice tungro bacilliform virus-like sequences in the rice genome: implications for integration and evolution. BMC Genomics 5, 80-93.

La Scola, B., Desnues, C., Pagnier, I., Robert, C., Barrassi, L., Fournous, G., Merchat, M., SuzanMonti, M., Forterre, P., Koonin, E. and Raoult, D., 2008. The virophage as a unique parasite of a giant mimivirus. Nature 455, 100-104.

Lauring, A.S. and Andino, R., 2010. Quasispecies theory and the behavior of RNA viruses. PLoS Pathog. 6(7):e1001005.

Le Gall, O., Christian, P., Fauquet, C.M., King, A.M., Knowles, N.J., Nakashima, N., Stanway, G. and Gorbalenya, A.E., 2008. Picornavirales, a proposed order of positive-sense singlestranded RNA viruses with a pseudo-T=3 architecture. Arch. Virol. 153, 715-727. 
Lefèvre, T., and Thomas, F. 2008. Behind the scene, something else is pulling the strings: Emphasizing parasitic manipulation in vector-borne diseases. Inf. Gen. Evol. 8, 504-519.

Lefeuvre, P., Lett, J.-M., Reynaud, B. and Martin, D.P., 2007. Avoidance of protein fold disruption in natural virus recombinants. PLoS Pathog. 3(11):e181.

Lefeuvre, P., Lett, J.-M., Varsani, A. and Martin, D.P., 2009. Widely Conserved Recombination Patterns among Single-Stranded DNA Viruses. J. Virol. 83, 2697-2707.

Legavre, T., Maia, I.G., Casse-Delbart, F., Bernardi, F. and Robaglia, C., 1996. Switches in the mode of transmission select for or against a poorly aphid-transmissible strain of potato virus Y with reduced helper component and virus accumulation. J. Gen. Virol. 77, 1343-1347.

Léonard, S., Plante, D., Wittmann, S., Daigneault, N., Fortin, M.G. and Laliberté, J.-F., 2000. Complex formation between potyirus VPg and translation eukaryotic initiation factor $4 \mathrm{E}$ correlates with virus infectivity. J. Virol. 74, 7730-7737.

Lewsey, M.G., Murphy, A.M., MacLean, D., Dalchau, N., Westwood, J.H., Macaulay, K., Bennett, M.H., Moulin, M., Hanke, D.E., Powell, G., Smith, A.G. and Carr, J.P., 2010. Disruption of two defensive signaling pathways by viral RNA silencing suppressor. Mol. Plant-Microbe Interact. 23, 835-845.

Li, F. and Ding, S.-W., 2006. Virus counterdefense: diverse strategies for evading the RNAsilencing immunity. Annu. Rev. Microbiol. 60, 503-531.

Lin, H.-X., Rubio, L., Smythe, A.B. and Falk, B.W., 2004. Molecular population genetics of Cucumber mosaic virus in California: evidence for founder effects and reassortment. J. Virol. 78, 6666-6675.

Locali-Fabris, E.C., Freitas-Astua, J., Souza, A.A., Takita, M.A., Astua-Monge, G., AntonioniLuizon, R., Rodrigues, V., Targon, M.L.P.N. and Machado, M.A., 2006. Complete nucleotide sequence, genomic organization and phylogenetic analysis of Citrus leprosis virus cytoplasmic type. J. Gen. Virol. 87, 2721-2729.

Malpica, J.M., Fraile, A., Moreno, I., Obies, C.I., Drake, J.W. and Garcia-Arenal, F., 2002. The rate and character of spontaneous mutation in an RNA virus. Genetics 162, 1505-1511.

Manrubia, S.C., Escarmis, C., Domingo, E. and Lazaro, E., 2005. High mutation rates, bottlenecks, and robusness of viral RNA quasispecies. Gene 347, 273-282.

Marée, A.F.M., Keulen, W., Boucher, C.A.B. and De Boer, R.J., 2000. Estimating relative fitness in viral competition experiments. J. Virol. 74, 11067-11072.

Márquez, L.M., Redman, R.S., Rodriguez, R.J. and Roossinck, M.J., 2007. A virus in a fungus in a plant: three-way symbiosis required for thermal tolerance. Science 315, 513-515.

Martelli, G.P., Adams, M.J., Kreuze, J.F. and Dolja, V.V., 2007. Family Flexiviridae: a case study in virion and genome plasticity. Annu. Rev. Phytopathol. 45, 73-100.

Mauck, K.E., De Moraes, C.M. and Mescher, M.C. 2010. Deceptive chemical signals induced by a plant virus attract insect vectors to inferior hosts. Proc. Natl. Acad.Sci. U.S.A 107, 36003605.

Maule, A.J., 2008. Plasmodesmata: structure, function and biogenesis. Curr. Opin. Plant Biol. 11, 680-686.

Mbanzibwa, D.R., Tian, Y., Mukasa, S.B. and Valkonen, J.P.T., 2009. Cassava Brown Streak Virus (Potyviridae) Encodes a Putative Maf/HAM1 Pyrophosphatase Implicated in Reduction of Mutations and a P1 Proteinase That Suppresses RNA Silencing but Contains No HC-Pro. J. Virol. 83, 6934-6940.

McDonald, B. and Linde, C., 2002. Pathogen population genetics, evolutionary potential, and durable resistance. Annu. Rev. Phytopathol. 40, 349-379.

Miller, W.A., Wang, Z. and Treder, K., 2007. The amazing diversity of cap-independent translation elements in the 3'-untranslated regions of plant viral RNAs. Bioch. Soc. Trans. 35, 16291633.

Miyashita, S. and Kishino, H., 2010. Estimation of the size of genetic bottlenecks in cell-to-cell movement of Soil-borne wheat mosaic virus (SBWMV) and the possible role of the 
bottlenecks in speeding up selection on variation in trans-acting genes or elements. J. Virol. 84, 1828-1837.

Moffett, P., 2009. Mechanisms of Recognition in Dominant R Gene Mediated Resistance. Adv. Virus Res. 75, 1-33.

Monsion, B., Froissart, R., Michalakis, Y. and Blanc, S., 2008. Large bottleneck size in Cauliflower mosaic virus populations during host plant colonization. PLoS Pathog. 4(10), e1000174.

Moreira, D. and Lopez-Garcia, P., 2009. Ten reasons to exclude viruses from the tree of life. Nat. Rev. Microbiol. 7, 306-311.

Morse, S., 1994. Toward an evolutionary biology of viruses. In: S.S. Morse (Ed), The evolutionary biology of viruses, pp. 1-28. Raven Press, Ltd., New York.

Moury, B., 2004. Differential selection of genes of Cucumber mosaic virus subgroups. Mol. Biol. Evol. 21, 1602-1611.

Moury, B., Desbiez, C., Jacquemond, M. and Lecoq, H. 2006. Genetic diversity of plant virus populations: towards hypothesis testing in molecular epidemiology. Adv. Virus Res. 67, 4987.

Moury, B., Fabre, F. and Senoussi, R.; 2007. Estimation of the number of particles transmitted by an insect vector. Proc. Natl. Acad.Sci. U.S.A 104, 17891-17896.

Muthukumar, V., Melcher, U., Pierce, M., Wiley, G.B., Roe, B.A., Palmer, M.W., Thapa, V., Ali, A. and Ding, T.; 2009. Non-cultivated plants of the Tallgrass Prairie Preserve of northeastern Oklahoma frequently contain virus-like sequences in particulate fractions. Virus Res. 141, 169-173.

Nagata, T., Inoue-Nagata, A.K., Prins, M., Goldbach, R. and Peters, D.; 2000. Impeded Thrips Transmission of Defective Tomato spotted wilt virus Isolates. Phytopathology 90, 454-459.

Ng, J.C.K. and Falk, B.W., 2006. Virus-vector interactions mediating nonpersistent and semipersistent transmission of plant viruses. Annu. Rev. Phytopathol. 44, 183-212.

Nolasco, G., Fonseca, F. and Silva, G., 2008. Occurrence of genetic bottleneck during citrus tristeza virus acquisitioin by Toxoptera citricida under field conditions. Arch. Virol. 153, 259-271.

Nürnberger, T. and Brunner, F., 2002. Innate immunity in plants and animals: emerging parallels between the recognition of general elicitors and pathogen-associated molecular patterns. Curr. Opin. Plant Biol. 5, 318-324.

Obbard, D., Gordon, K., Buck, A. and Jiggins, F., 2009. The evolution of RNAi as a defence against viruses and transposable elements. Phil. Trans. R. Soc. B 364, 99-115.

Ohshima, K., Tomitaka, Y., Wood, J.T., Minematsu, Y., Kajiyama, H., Tomimura, K. and Gibbs, A.J., 2007. Patterns of recombination in turnip mosaic virus genomic sequences indicate hotspots of recombination. J. Gen. Virol. 88, 298-315.

Ooi, K. and Yahara, T., 1999. Genetic variation of geminiviruses: comparison between sexual and asexual host populations. Mol. Ecol. 8, 89-97.

Paalme, V., Gammelgard, E., Järvekülg, L. and Valkonen, J.P.T., 2004. In vitro recombinants of two nearly identical potyviral isolates express novel virulence and symptom phenotypes in plants. J. Gen. Virol. 85, 739-747.

Paape, M., Solovyev, A.G., Erokhina, T.N., Minina, E.A., Schepetilnikov, M.V., Lesemann, D.E., Schiemann, J., Morozov, S.Y. and Kellmann, J.W., 2006. At-4/1, an interactor of the Tomato spotted wilt virus movement protein, belongs to a new family of plant proteins capable of directed intra- and intercellular trafficking. Mol. Plant-Microbe Interact. 19, 874-883.

Pagan, I., Alonso-Blanco, C. and Garcia-Arenal, F., 2009. Differential Tolerance to Direct and Indirect Density-Dependent Costs of Viral Infection in Arabidopsis thaliana. PLoS Pathog. 5(7), e1000531.

Pagan, I. and Holmes, E.C., 2010. Long-Term Evolution of the Luteoviridae: Time Scale and Mode of Virus Speciation. J. Virol. 84, 6177-6187.

Pagan, I., Firth, C. and Holmes, E.C., 2010. Phylogenetic Analysis Reveals Rapid Evolutionary Dynamics in the Plant RNA Virus Genus Tobamovirus. J. Mol. Evol. 71, 298-307. 
Paredes, R., Sagar, M., Marconi, V.C.H., R, Martin, J.N., Parkin, N.T., Petropoulos, C.J., Deeks, S.G. and Kuritzkes, D.R., 2009. In vivo fitness cost of the M184V mutation in multidrugresistant human immunodeficiency virus type 1 in the absence of lamivudine. J. Virol. 83, 2038-2043.

Peix, A., Ramirez-Bahena, M.-H. and Velazquez, E., 2009. Historical evolution and current status of the taxonomy of genus Pseudomonas. Inf. Gen. Evol. 9, 1132-1149.

Peter, K.A., Gildow, F., Palukaitis, P. and Gray, S.M., 2009. The C Terminus of the Polerovirus P5 Readthrough Domain Limits Virus Infection to the Phloem. J. Virol. 83, 5419-5429.

Pfeiffer, J.K. and Kirkegaard, K., 2006. Bottleneck-mediated quasispecies restriction during spread of an RNA virus from inoculation site to brain. Proc. Nat. Acad. Sci. USA 103, 5520-5525.

Pierrugues, O., Guilbaud, L., Fernandez-Delmond, I., Fabre, F., Tepfer, M. and Jacquemond, M., 2007. Biological properties and relative fitness of inter-subgroup cucumber mosaic virus RNA 3 recombinants produced in vitro. J. Gen. Virol. 88, 2852-2861.

Pirone, T.P. and Blanc, S., 1996. Helper-dependent vector transmission of plant viruses. Annu. Rev. Phytopathol. 34, 227-247.

Pita, J.S., Fondong, V.N., Sangaré, A., Otim-Nape, G.W., Ogwal, S. and Fauquet, C., 2001. Recombination, pseudorecombination and synergism of geminiviruses are determinant keys to the epidemic of severe cassava mosaic disease in Uganda. J. Gen. Virol. 82, 655-665.

Pond, S.L. and Frost, S.D., 2005. Datamonkey: rapid detection of selective pressure on individual sites of codon alignments. Bioinformatics 21, 2531-2533.

Poutaraud, A., Desbiez, C., Lemaire, O., Lecoq, H. and Herrbach, E., 2004. Characterization of a new potyvirus species infecting meadow saffron (Colchicum autumnale). Arch. Virol. 149, 1267-1277.

Power, A.G. and Mitchell, C.E., 2004. Pathogen Spillover in Disease Epidemics. Am. Nat. 164, S79-S89.

Pu, Y., Kikuchi, A., Tomaru, M., Jin, Y., Suga, S., Hagiwara, K., Akita, F., Shimizu, T., Netsu, O., Suzuki, N., Uehara-Ichiki, T., Sasaya, T., Wei, T., Li, Y. and Omura, T., 2011. Rice dwarf viruses with dysfunctional genomes generated in plants are filtered out in vector insects implications for the virus origin. J. Virol. doi:10.1128/JVI.02147-10.

Purugganan, M.D. and Fuller, D.Q., 2009. The nature of selection during plant domestication. Nature 457, 843-848.

Raoult, D., Audic, S., Robert, C., Abergel, C., Renesto, P., Ogata, H., La Scola, B., Suzan, M. and Claverie, J.-M., 2004. The 1.2 Megabase genome sequence of Mimivirus. Science 306, 13441350.

Raoult, D. and Forterre, P., 2008. Redefining viruses: lessons from Mimivirus. Nat. Rev. Microbiol. 6, 315-319.

Resende, R., de Haan, P., de Avila, A.C., Kitajima, E.W., Kormelink, R., Goldbach, R. and Peters, D., 1991. Generation of envelope and defective interfering RNA mutants of tomato spotted wilt virus by mechanical passage. J. Gen. Virol. 72, 2375-2383.

Rice, W., 1983. Sexual reproduction: an adaptation reducing parent-offspring contagion. Evolution 37, 1317-1320.

Richman, D.D., 2006. Antiviral drug resistance. Antiviral Res. 71, 117-121.

Riley, M.-A. and Lizotte-Waniewski, M., 2009. Population genomics and the bacterial species concept. Meth. Mol. Biol. 532, 367-377.

Rodoni, B., 2009. The role of plant biosecurity in preventing and controlling emerging

plant virus disease epidemics. Virus Res. 141, 150-157.

Roossinck, M., 2003. Plant RNA virus evolution. Curr. Opin. Microbiol. 6, 406-409.

Roossinck, M., 2010. Lifestyles of plant viruses. Phil. Trans. R. Soc. B 365, 1899-1905.

Roossinck, M.J., 1997. Mechanisms of plant virus evolution. Annu. Rev. Phytopathol. 35, 191-209.

Roossinck, M.J., Saha, P., Wiley, G.B., Quan, J., White, J.D., Lai, H., Chavarria, F., Shen, G. and Roe, B.A., 2010. Ecogenomics: using massively parallel pyrosequencing to understand virus ecology. Mol. Ecol. 19 (s1), 81-88. 
Roy, B.A. and Kirchner, J.W., 2000. Evolutionary dynamics of pathogen resistance and tolerance. Evolution 54, 51-63.

Sacristan, S. and Garcia-Arenal, F., 2008. The evolution of virulence and pathogenicity in plant pathogen populations. Mol. Plant Pathol. 9, 369-384.

Sacristan, S., Malpica, J.M., Fraile, A. and Garcia-Arenal, F., 2003. Estimation of population bottlenecks during systemic movement of Tobacco mosaic virus in tobacco plants. J. Virol. 77, 9906-9911.

Salomon, R., 1999. The evolutionary advantage of breeding for tolerance over resistance against viral plant diseases. Israel J Plant Sci. 47, 135-139.

Sanjuan, R., 2010. Mutational fitness effects in RNA and single-stranded DNA mutagenesis studies viruses: common patterns revealed by site-directed. Phil. Trans. R. Soc. B 365, 1975-1982.

Sanjuan, R., Agudelo-Romero, P. and Elena, S.F., 2009. Upper-limit mutation rate estimation for a plant RNA virus. Biol. Letters 5, 394-396.

Sanjuan, R., Nebot, M.R., Chirico, N., Mansky, L.M. and Belshaw, R., 2010. Viral mutation rates. J. Virol. 84, 9733-9738.

Scott White, P., Morales, F. and Roossinck, M.J., 1995. Interspecific reassortment of genomic segments in the evolution of cucumoviruses. Virology 207, 334-337.

Shiboleth, Y.M., Haronsky, E., Leibman, D., Arazi, T., Wassenegger, M., Whitham, S.A., Gaba, V. and Gal-On, A., 2007. The conserved FRNK box in HC-Pro, a plant viral suppressor of gene silencing, is required for small RNA binding and mediates symptom development. J. Virol. 81, 13135-13148.

Sin, S.-H., McNulty, B.C., Kennedy, G.G. and Moyer, J.W., 2005. Viral genetic determinants for thrips transmission of Tomato spotted wilt virus. Proc. Natl. Acad.Sci. U.S.A 102, 5168-5173.

Smith, D.B., McAllister, J., Casino, C. and Simmonds, P., 1997. Virus 'quasispecies': making a mountain out of a molehill? J. Gen. Virol. 78, 1511-1519.

Srinivasan, R. and Alvarez, J.M., 2007. Effect of mixed viral infections (Potato virus Y-Potato leafroll virus) on biology and preference of vectors Myzus persicae and Macrosiphum euphorbiae (Hemiptera : Aphididae). J. Econ. Entom. 100(3), 646-655.

Staginnus, C. and Richert-Pöggeler, K.R., 2006. Endogenous pararetroviruses: two-faced travelers in the plant genome. Trends Plant Sci. 11, 485-491.

Stewart, A.D., Logsdon, J.M. and Kelley, S.E., 2005. An empirical study of the evolution of virulence under both horizontal and vertical transmission. Evolution 59, 730-739.

Susaimuthu, J., Tzanetakis, I.E., Gergerich, R.C. and Martin, R.R., 2008. A member of a new genus in the Potyviridae infects rubus. Virus Res. 131, 145-151.

Takahashi, T., Sugawara, T., Yamatsuta, T., Isogai, M., Natsuaki, T. and Yoshikawa, N., 2007. Analysis of the spatial distribution of identical and two distinct virus populations differently labeled with cyan and yellow fluorescent proteins in coinfected plants. Phytopathology 97, 1200-1207.

Tromas, N. and Elena, S., 2010. The rate and spectrum of spontaneous mutations in a plant RNA virus. Genetics 15, 436-446.

Truniger, V. and Aranda, M.A., 2009. Recessive resistance to plant viruses. Adv. Virus Res. 75, 119-159.

Tsagris, E.M., de Alba, A.E.M., Gozmanova, M. and Kalanditis, K., 2008. Viroids. Cell. Microbiol. 10, 2168-2179.

Uzest, M., Gargani, D., Drucker, M., Hébrard, E., Garzo, E., Candresse, T., Fereres, A. and Blanc, S., 2007. A protein key to plant virus transmission at the tip of the insect vector stylet. Proc. Natl. Acad.Sci. U.S.A 104, 17959-17964.

Valli, A., Lopez-Moya, J.-J. and Garcia, J.A., 2007. Recombination and gene duplication in the evolutionary diversification of P1 proteins in the family Potyviridae. J. Gen. Virol. 88, 10161028. 
van den Born, E., Omelchenko, M.V., Bekkelund, A., Leihne, V., Koonin, E.V., Dolja, V.V. and Falnes, P.O., 2008. Viral AlkB proteins repair RNA damage by oxidative demethylation. Nucleic Acids Res. 36, 5451-5461.

van den Bosch, F., Akudibilah, G., Seal, S. and Jeger, M., 2006. Host resistance and evolutionary response of plant viruses. J. Appl. Ecol. 43, 506-516.

van der Walt, E., Rybicki, E., Varsani, A., Polston, J.E., Billharz, R., Donaldson, L., Monjane, A.L. and Martin, D.P., 2009. Rapid host adaptation by extensive recombination. J. Gen. Virol. 90, 734-746.

Vega-Rocha, S., Gronenborn, B., Gronenborn, A. and Campos-Olivas, R., 2007. Solution structure of the endonuclease domain from the master replication initiator protein of the nanovirus faba bean necrotic yellows virus and comparison with the corresponding geminivirus and circovirus structures. Biochemistry 46, 6201-6212.

Wallis, C.M., Stone, A.L., Sherman, D.J., Damsteegt, V.D., Gildow, F.E. and Schneider, W.L., 2007. Adaptation of plum pox virus to a herbaceous host (Pisum sativum) following serial passages. J. Gen. Virol. 88, 2839-2845.

Wren, J.D., Roossinck, M., Nelson, R.S., Scheets, K., Palmer, M.W. and Melcher, U., 2006. Plant virus diversity and ecology. PLoS Biol. 4(3):e80.

Xu, P., Chen, F., Mannas, J.P., Feldman, T., Sumner, L.W. and Roossinck, M.J., 2008. Virus infection improves drought tolerance. New Phytol. 180, 911-921.

Zaccomer, B., Haenni, A.-L. and Macaya, G., 1995. The remarkable variety of plant RNA virus genomes. J. Gen. Virol. 76, 231-247. 


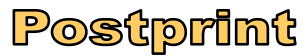

Version définitive du manuscrit publié dans/ Final version of the manuscript published in: Infection, Genetics and Evolution, 2011,11, 812-824. The original publication is available at http://www.sciencedirect.com/science/article/pii/S1567134811000621. DOI: 10.1016/j.meegid.2011.02.020.

Table 1: Families and genera of viruses infecting plants

\begin{tabular}{|c|c|c|c|c|c|c|c|c|c|}
\hline & Order $^{(a)}$ & Family/Subfamily ${ }^{(a)}$ & Genus $^{(a)}$ & $\begin{array}{l}\text { Number of } \\
\text { species }^{(\mathfrak{b})}\end{array}$ & Envelope & Virion shape & $\begin{array}{l}\text { Genome size } \\
\text { (in kilobases) }^{(f)}\end{array}$ & $\begin{array}{l}\text { Number of } \\
\text { components }\end{array}$ & $\begin{array}{l}\text { Vector or mode of } \\
\text { transmission }^{(g)}\end{array}$ \\
\hline dsDNA (no RT) & None & & & & & & & & \\
\hline \multirow{6}{*}{ dsDNA (RT) } & No order & Caulimoviridae & Caulimovirus & 8 & - & Icosahedral & 8 & 1 & Aphid \\
\hline & No order & Caulimoviridae & Cavemovirus & 2 & - & Icosahedral/bacilliform & 8 & 1 & Vegetative propagation \\
\hline & No order & Caulimoviridae & Petuvirus & 1 & - & Bacilliform & 7.2 & 1 & Vertical transmission, grafting \\
\hline & No order & Caulimoviridae & Soymovirus & 3 & - & Icosahedral & 8 & 1 & Vegetative propagation \\
\hline & No order & Caulimoviridae & Badnavirus & 18 & - & Bacilliform & 7.2 & 1 & $\begin{array}{l}\text { Mealybug or lacebug or aphid, } \\
\text { vegetative propagation }\end{array}$ \\
\hline & No order & Caulimoviridae & Tungrovirus & 1 & - & Bacilliform & 8 & 1 & Leafhopper \\
\hline \multirow[t]{6}{*}{ ssDNA } & No order & Geminiviridae & Begomovirus & 196 & - & Double icosahedral & 2.8 or $2 \times 2.8$ & 1 or 2 & Whitefly \\
\hline & No order & Geminiviridae & Mastrevirus & 14 & - & Double icosahedral & 3 & 1 & Leafhopper \\
\hline & No order & Geminiviridae & Curtovirus & 7 & - & Double icosahedral & 3 & 1 & Leafhopper \\
\hline & No order & Geminiviridae & Topocuvirus & 1 & - & Double icosahedral & 3 & 1 & Treehopper \\
\hline & No order & Nanoviridae & Nanovirus & 3 & - & Icosahedral & (6 to 9$)$ & 6 to 9 & Aphid \\
\hline & No order & Nanoviridae & Babuvirus & 3 & - & Icosahedral & 6 & 6 & Aphid \\
\hline \multirow[t]{5}{*}{ dsRNA } & No order & Partitiviridae (F) & Alphacryptovirus & 16 & - & Icosahedral & $2+1.7$ & 2 & Vertical transmission \\
\hline & No order & $\begin{array}{l}\text { Reoviridae/Spinareovirinae } \\
(\mathrm{V}, \mathrm{I}, \mathrm{F})\end{array}$ & Fijivirus (I) & 8 & - & Icosahedral & (29) & 10 & Planthopper \\
\hline & No order & Reoviridae/Sedoreovirinae $(\mathrm{V}, \mathrm{I})$ & Phytoreovirus (I) & 3 & - & Icosahedral & $(24)$ & 12 & Leafhopper \\
\hline & No order & $\begin{array}{l}\text { Reoviridae/Spinareovirinae } \\
(\mathrm{V}, \mathrm{I}, \mathrm{F})\end{array}$ & Oryzavirus (I) & 2 & - & Icosahedral & (26) & 10 & Planthopper \\
\hline & No order & Endornaviridae $(\mathrm{F})$ & Endornavirus (F) & 6 & - & - & $14-18$ & 1 & Vertical transmission \\
\hline \multirow[t]{3}{*}{ ssRNA(RT) } & No order & Pseudoviridae $(\mathrm{I}, \mathrm{F})$ & Pseudovirus (F) & 20 & - & Icosahedral & $5-6$ & 1 & Vertical transmission \\
\hline & No order & Pseudoviridae $(\mathrm{I}, \mathrm{F})$ & Sirevirus & 5 & - & Icosahedral & 9 & 1 & Vertical transmission \\
\hline & No order & Metaviridae $(\mathrm{I}, \mathrm{F})$ & Metavirus $(\mathrm{I}, \mathrm{F})$ & 21 & - & Spherical/irregular ${ }^{(c)}$ & 4 to 10 & 1 & Vertical transmission \\
\hline \multirow[t]{5}{*}{ ssRNA- } & Mononegavirale $(\mathrm{V}, \mathrm{I}, \mathrm{F})$ & Rhabdoviridae $(\mathrm{V}, \mathrm{I})$ & Cytorhabdovirus (I) & 9 & + & Enveloped & 13 & 1 & Aphid or leafhopper \\
\hline & Mononegavirale $(\mathrm{V}, \mathrm{I}, \mathrm{F})$ & Rhabdoviridae $(\mathrm{V}, \mathrm{I})$ & Nucleorhabdovirus (I) & 9 & + & Enveloped & 12 to 14 & 1 & Aphid or leafhopper \\
\hline & No order & Bunyaviridae $(\mathrm{V}, \mathrm{I})$ & Tospovirus (I) & 8 & + & Enveloped & $8.9+4.8+3$ & 3 & Thrips \\
\hline & No order & Ophioviridae & Ophiovirus & 6 & - & Filamentous & (11.3) to (12.5) & 3 or 4 & Soil fungus \\
\hline & No order & No family & Varicosavirus & 1 & - & Rod shaped & $6.8+6.1$ & 2 & Soil fungus \\
\hline
\end{tabular}




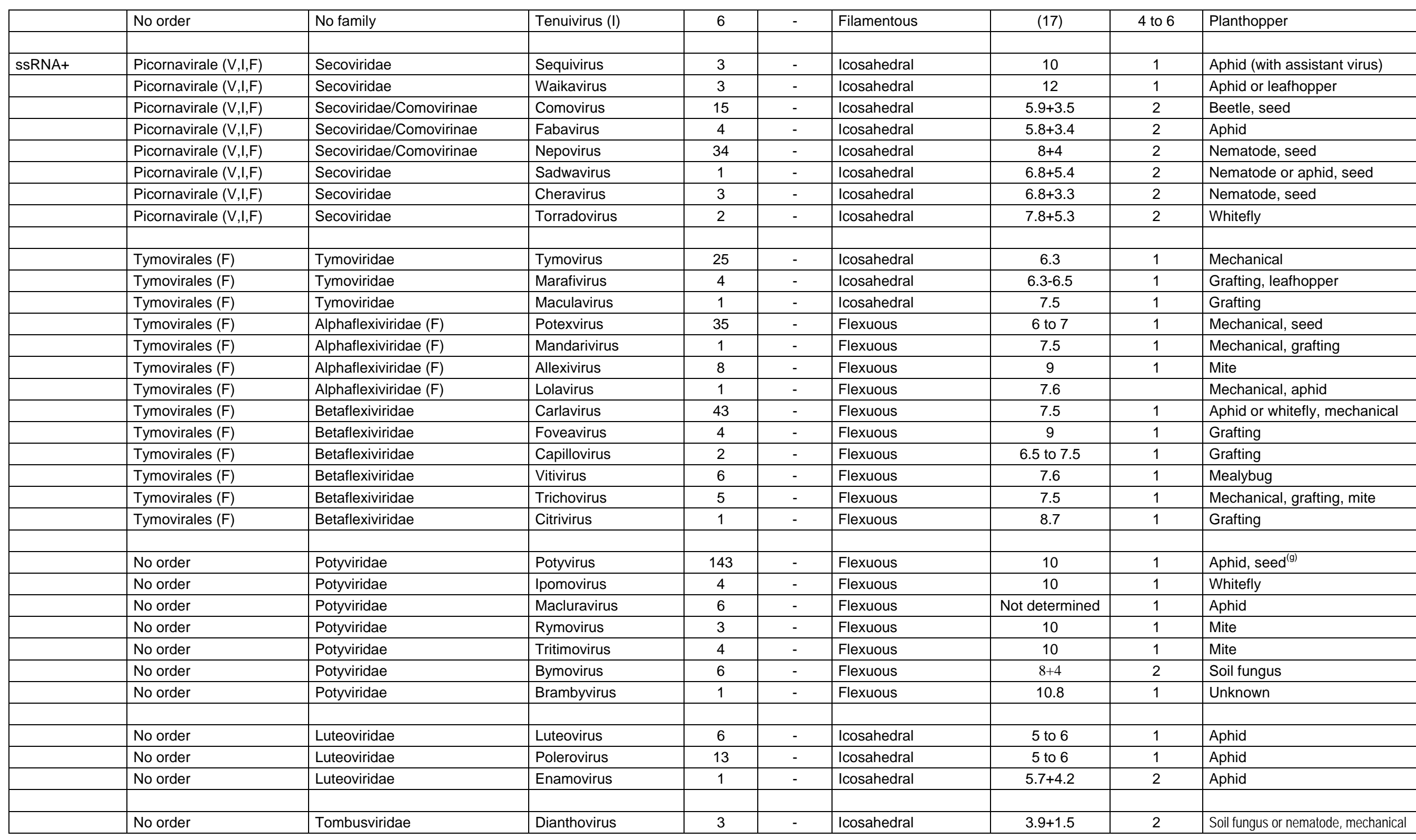




\begin{tabular}{|c|c|c|c|c|c|c|c|c|c|}
\hline & No order & Tombusviridae & Tombusvirus & 17 & - & Icosahedral & 4.7 & 1 & Soil fungus, mechanical \\
\hline & No order & Tombusviridae & Aureusvirus & 4 & - & Icosahedral & 4.4 & 1 & Soil, mechanical \\
\hline & No order & Tombusviridae & Avenavirus & 1 & - & Icosahedral & 4.1 & 1 & Mechanical \\
\hline & No order & Tombusviridae & Carmovirus & 16 & - & Icosahedral & 4 & 1 & $\begin{array}{l}\text { Mechanical, soil fungus or } \\
\text { beetle, seed }\end{array}$ \\
\hline & No order & Tombusviridae & Necrovirus & 7 & - & Icosahedral & 3.8 & 1 & Soil fungus, mechanical \\
\hline & No order & Tombusviridae & Panicovirus & 1 & - & Icosahedral & 4.3 & 1 & Mechanical \\
\hline & No order & Tombusviridae & Machlomovirus & 1 & - & Icosahedral & 4,4 & 1 & Mechanical \\
\hline & No order & Bromoviridae & Alfamovirus & 1 & - & Several sizes & $3.6+2.6+2$ & 3 & Aphid, seed, mechanical \\
\hline & No order & Bromoviridae & Bromovirus & 6 & - & Icosahedral & $3.2+2.9+2.1$ & 3 & Mechanical, aphid or beetle \\
\hline & No order & Bromoviridae & Cucumovirus & 3 & - & Icosahedral & $3.4+3+2.2$ & 3 & Aphid, seed \\
\hline & No order & Bromoviridae & Ilarvirus & 16 & - & Icosahedral & $2.9+2.8+2.2$ & 3 & Mechanical, pollen, seed \\
\hline & No order & Bromoviridae & Oleavirus & 1 & - & Several sizes & $3.1+2.7+2.4$ & 3 & Mechanical \\
\hline & No order & Bromoviridae & Anulavirus & 1 & - & Icosahedral & $3.4+2.4+2.5$ & 3 & Mechanical, pollen \\
\hline & No order & Closteroviridae & Closterovirus & 9 & - & Flexuous & 15.5 & 1 & Aphid \\
\hline & No order & Closteroviridae & Crinivirus & 12 & - & Flexuous & $8+7$ & 2 & Whitefly \\
\hline & No order & Closteroviridae & Ampelovirus & 8 & - & Flexuous & $17-18$ & 1 & Mealybug \\
\hline & No order & Virgaviridae & Tobamovirus & 25 & - & Rod-shaped & 6.4 & 1 & Mechanical, seed \\
\hline & No order & Virgaviridae & Tobravirus & 3 & - & Rod-shaped & $6.8+(1.8$ to 4.5$)$ & 2 & Nematode, mechanical \\
\hline & No order & Virgaviridae & Hordeivirus & 4 & - & Rod-shaped & $3.8+3.3+2.8$ & 3 & Mechanical, seed, pollen \\
\hline & No order & Virgaviridae & Furovirus & 5 & - & Rod-shaped & $7+3.6$ & 2 & Soil fungus, seed \\
\hline & No order & Virgaviridae & Pomovirus & 4 & - & Rod-shaped & $5.8+3.5+3$ & 3 & Soil fungus \\
\hline & No order & Virgaviridae & Pecluvirus & 2 & - & Rod-shaped & $5.9+4.5$ & 2 & Soil fungus, seed \\
\hline & No order & No family & Renyiruc & 2 & - & Bod_chanod & $68+17$ & 2 & Soil fungur \\
\hline & No order & No family & Sobemovirus & 13 & - & Icosahedral & 4.2 & $\frac{2}{1}$ & Mechanical, beetle \\
\hline & No order & No family & Cilevirus $^{(\mathrm{d})}$ & 1 & + & Bacilliform & $8.7+5$ & 2 & Mites \\
\hline & No order & No family & Ourmiavirus & 3 & - & several sizes & $2.8+1+1$ & 3 & Mechanical \\
\hline & No order & No family & Umbravirus & 7 & - & - & 4.5 & 1 & Aphid (with assistant virus) \\
\hline & No order & No family & Idaeovirus & 1 & - & Icosahedral & $5.5+2.2$ & 2 & Mechanical, pollen \\
\hline & No order & No family & Polemovirus $^{(\mathrm{e})}$ & 1 & & Icosahedral & 4.6 & 1 & Vegetative propagation, graft \\
\hline Viroids & No order & Pospiviroidae & Pospiviroid & 9 & - & - & 0.36 & 1 & Vegetative propagation, aphid \\
\hline & No order & Pospiviroidae & Hostuviroid & 1 & - & - & 0.3 & 1 & Vegetative propagation \\
\hline
\end{tabular}




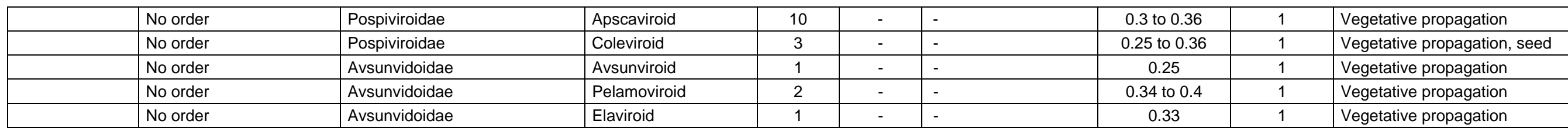

(a) Members of the order, family or genus infect vertebrates (V), insects (I) or fungi (F)

(b) As accepted by the ICTV in 2009

(c) Formation of intracellular virus-like particles (VLP) but their structure is not well known

(d) Considered as a ssRNA(+) virus based on sequence similarities, but not proven (Locali-Fabris et al., 2006)

(e) Recombinant between a polerovirus and a sobemovirus (aus dem Siepen et al., 2005)

(f) In brackets: total size of the genome for segmented viruses

(g) Can involve only some species in the genus and/or only some hosts 